\title{
The Lower Kimmeridge Clay at Westbury, Wiltshire, England
}

\author{
T. Birkelund, J. H. Callomon, C. K. Clausen, H. Nøhr Hansen and I. Salinas
}

\begin{abstract}
BIRKELUND, T., J. H. CALlOMON, C. K. CLAUSEN, H. NØHR HANSEN \& I. SALINAS, 1983. The Lower Kimmeridge Clay at Westbury, Wiltshire, England. Proc. Geol. Ass. 94 (4), 289-309. A section is described through $40 \mathrm{~m}$ of the Jurassic Lower Kimmeridge Clay at Westbury cement-works, Wiltshire. It extends from the upper Rasenia cymodoce Zone $(3 \mathrm{~m})$ through the whole of the Aulacostephanoides mutabilis Zone $(22.3 \mathrm{~m})$ into the lower Aulacostephanus eudoxus Zone $(14.5 \mathrm{~m})$ of the Kimmeridgian, together divisible into some 30 beds. Ammonites and bivalves occur in profusion with other groups as subsidiary elements, and assemblages of varying diversity and association are recorded bed by bed. The succession can be correlated very closely with those of eastern England (Wash boreholes), the Dorset coast and the Aquitaine Basin in western France. Two sharp and major discontinuities in the ammonite succession at Westbury can be recognized over this whole area and are proposed as basis for formal definitions (by their bases) of the Mutabilis and Eudoxus Zones. The exposure of the Mutabilis Zone at Westbury is the best recorded so far, and makes it possible to delimit the zone satisfactorily for the first time both there and on the Dorset coast.
\end{abstract}

T. Birkelund, C. K. Clausen, H. Nøhr Hansen and I. Salinas, Institut for historisk geologi og palaeontologi, Oster Voldgade 10, 1350 Copenhagen, Denmark.

J. H. Callomon, Department of Chemistry, University College, 20 Gordon St, London WC1H $O A J$.

\section{INTRODUCTION}

The Lower Kimmeridge Clay is one of the last parts of the British Jurassic to await a modern stratigraphical revision. The main obstacle has been lack of exposures. The only permanent and readily accessible outcrops are on the Dorset coast, but weathering of the soft shales and landslips make recovery of well-preserved material difficult; the exposures become good only from a level near the top of the Lower Kimmeridge Clay upwards (Arkell, 1947; Cope, 1980).

The lithostratigraphy south of the Humber has been surveyed in considerable detail in recent years by the Institute of Geological Sciences, based mainly on the evidence of borings (Callomon \& Cope, 1971; Gallois \& Cox, 1976; Gallois, 1978) but including a revision of what there is to be seen on the Dorset coast (Cox \& Gallois, 1981). These studies have revealed a succession that is remarkably constant over the whole area. Individual beds can often be followed by their lithology and their fossils over distances of 100-200 $\mathrm{km}$. Lithostratigraphic correlation and classification are therefore rather complete. Chronostratigraphic classification is less satisfactory. Relatively little has been done in Britain since the time of Salfeld (1913. 1914) who set up the ammonite zonation for the sub-Boreal Anglo-Saxon Province in use to-day. $\mathrm{He}$ subdivided the Lower Kimmeridgian Stage sensu anglico which, following original French usage that is becoming the internationally accepted usage, was for him the whole of the Kimmeridgian, into five standard ammonite Zones: Baylei (lowest), Cymodoce, Mutabilis, Yo and Pseudomutabilis (highest). The last two were replaced by two others by Ziegler (1962): Eudoxus and Autissiodorensis Zones, respectively. This scheme used without qualification has now become an oversimplification that conceals a succession of faunas. The part least well known is the Mutabilis Zone. A revision has become urgent, for the Lower Kimmeridgian was a period marked by major changes of sedimentary regime, for example widespread anoxic events, that extended from Greenland in the north to the Aquitaine Basin in the south and the Russian Platform in the east. These changes were accompanied by important developments in the evolution of the ammonites, which became strongly segregated into a number of distinct faunal provinces, thereby raising problems of correlation. They are also reflected in the non-ammonoid organisms, which span a rich spectrum of facies and diversity hitherto hardly examined.

We describe here a major section of some permanence in a clay-pit dug for cement-making at the Blue Circle Portland Cement Company's works at Westbury, Wilts. (Grid Reference ST 882528). The beds dip $5^{\circ}$ SSE and expose some $41 \mathrm{~m}$ of Kimmeridge Clay, including the upper Cymodoce Zone $(2.5 \mathrm{~m})$, the whole of the Mutabilis Zone $(23.3 \mathrm{~m})$ and the lower Eudoxus Zone $(14.5 \mathrm{~m})$. The richness and diversity of the fossil faunas is immense at almost all horizons, and the present description is intended as a framework to which more detailed studies on microand macro-faunas, stratigraphy and geochemistry may be related later. 


\section{LITHO-AND BIOSTRATIGRAPHY}

\section{(a) The section}

The clays of the area rest on the Westbury Ironstone, once mined for ore, and the Corallian Beds of the Oxfordian. These lower, harder beds are well known from outcrops (Arkell, 1933; Wright, 1980) and are also met with in borings to explore reserves around the clay pit. A summary of one of these, put down in 1979 near the NW corner of the pit, is included here to complete the succession from below. It is taken from a $\log$ prepared by R. W. Gallois for Blue Circle. Correlations of some of the beds with named units on the Dorset coast (Cox \& Gallois, 1981, fig. 2) present no problems and are indicated in square brackets. Zonal boundaries are sharp, and it is therefore convenient to number beds in each zone separately. The prefixes $B, C, M$, and $E$ refer to Baylei, Cymodoce, Mutabilis and Eudoxus Zones respectively. (C), (R) = common, rare, etc.; (M) and (m), ammonite macro- and microconchs; bivalves determined mostly to generic level.

\section{From below: borehole log}

\section{Upper Oxfordian}

Thickness, $\mathrm{m}$

-Osmington Oolite Formation, Calne Freestone: limestone, oolitic to pisolitic, shelly, crossbedded, bioturbated in lower part

-Glos Oolite Formation, Upper Calcareous Grit: limestones, in part oolitic, mudstones and sandstones, in part glauconitic, heavily bioturbated

-Westbury Ironstone (Pseudocordata Zone and Subzone, type area): limonitic and chamositic oolites, heavily burrowed; shelly at several levels, with oysters, serpulids, a belemnite

-[Ringstead Waxy Clays]: mudstones, calcareous, smooth-textured; poorly fossiliferous, Deltoideum ['Ostrea'] delta common at some levels

Kimmeridgian. Lower Kimmeridge Clay.

Baylei Zone

B1 Mudstone, medium grey, very silty, intensely burrowed; nests of Nanogyra, serpula-encrusted $D$. delta, and other bivalves

B2 Mudstone, pale grey, shelly; small oysters, Procerithium and serpulids

B3 Mudstone, pale grey, calcareous, phosphatized in patches, almost barren, silty and burrowed at base

Cymodoce Zone

C1 Siltstone [Wyke Siltstone] pale greenish grey, burrowed, interburrowed junction at base, oysters

C2 Mudstone, dark, shelly, plasters of serpulaencrusted oysters; interburrowed base

C3 Mudstone, dark, sparsely shelly, pyritic Chondrites
C4 Mudstone and greenish quartzose siltstone [Black Head Siltstone], heavily burrowed, oyster plaster near interburrowed base

C5 Clays, dark grey, smooth textured, variably shelly, lower $4 \mathrm{~m}$ known only from borehole, upper $2.5 \mathrm{~m}$ seen in drainage pit at bottom of clay pit. Total thickness

Fossil content divides the bed into parts:

(a) Clays, variably shelly, in borehole

end of borehole log-beginning of pit exposure

(b) Poorly fossiliferous clay with scattered ammonites and bivalves. Rasenia cf. involuta Spath (m) \& (M), Thracia and Palaeonucula; seen in pit to

(c) More fossiliferous clay. Ammonites well preserved, complete, and although not in plasters, tending to be concentrated around certain levels, particularly between 30 and $45 \mathrm{~cm}$ up (95-110 $\mathrm{cm}$ below the marker concretions of bed C6). Rasenia involuta Spath and forms transitional to $R$. evoluta Spath, (m) \& (M); Rasenioides cf. or aff. thermarum (Oppel). Liostrea as widespread incrustation of ammonites; Isocyprina (VC), Palaeonucula; Lingula ovalis J. Sowerby

(d) Highly fossiliferous shaly clay with much shell debris; few ammonites; Thracia (VC)

(e) Fossil plaster at base with many ammonites ['Xenostephanus' bed of Cox \& Gallois], becoming less fossiliferous upwards. Rasenia evoluta Spath (m) \& (M), typical evolute forms, the microconchs coarsely bi- or triplicate on the outer whorl, some resembling Xenostephanus when crushed but inner whorls still distinctly rasenid and not aulacostephanid; also rare

5.80 fine-ribbed Rasenioides of the striolaristhermarum group, quite distinct, without intermediates; Lingula, large Liostrea, Thracia - sharp boundary --

4.60 C6 Marker: clays, light grey, calcareous, harder, blocky fracture, with layer of large ovoid septarian concretions up to $25 \mathrm{~cm}$ thick in the lower part of the bed. Only moderately fossiliferous: Rasenia sp. (R); Thracia (VC), Corbulomima, Lingula (C)

$$
\text { - sharp boundary - }
$$

Mutabilis Zone c. 1.0
M1 Clays, silty, weathering light grey, moderately shelly to highly shelly at the top. Ammonites profuse at certain levels, concentrated almost to plasters at 0.2 and $3.7 \mathrm{~m}$ up; a thin shell plaster $1.4 \mathrm{~m}$ above base. Fossils beautifully preserved, the ammonites strongly iridescent: Raseniodes (Semirasenia) askeptus Ziegler (M) and $(R)$. (Rasenioides) lepidulus (Oppel), cf. moeschi (Oppel), thermarum (Oppel) (m) (all VC), the macroconchs complete and smooth with end-diameters $100-150 \mathrm{~mm}$, the microconchs with long lappets; Rasenia cf. coronata Mesezhnikov (M) (R), at 2.0 and $3.7 \mathrm{~m}$ above base. Astarte, Corbulomima and Nucinella (VC); Thracia (C) and Nanogyra (C), the 


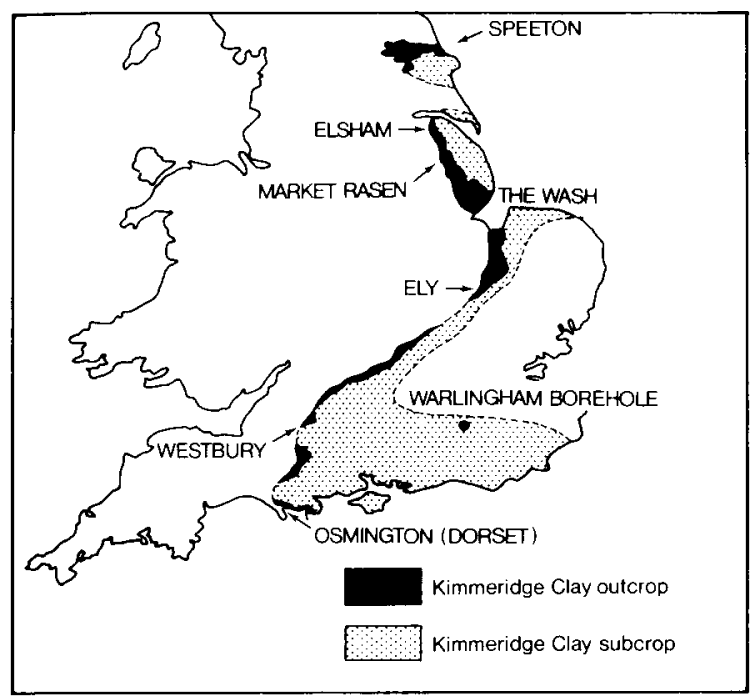

Fig. 1. Map showing the Kimmeridge Clay outcrop and subcrop and the position of localities mentioned in the text.

lowest appearance of the virgula group; occasional Entolium, Protocardia and Liostrea.

M2 Clay, silty, compact, dark, only sparsely shelly, bivalves poorly preserved. Ammonite bed $0.30 \mathrm{~m}$ up with abundant fine-ribbed rasenids as before ascribable to Rasenioides (m) and Involuticeras (M). Isocyprina, Corbulomima and Astarte (C)

M3 Clay, silty, compact, weathering light grey and forming a prominent feature within the otherwise dark mass of the beds above and below. Fine-ribbed rasenid ammonites as below. Diverse bivalve assemblage, Palaeonucula and Isocyprina dominant; layer of pyritic shells $10 \mathrm{~cm}$ above base, mainly Liostrea

M4 Clay, silty, dark, with scattered well-preserved shells. Ammonite plaster about halfway up with macroconchs now up to $250 \mathrm{~mm}$ in diameter, fine-ribbed species as below, approaching Aulacostephanoides aff. mutabilis in appearance. Astarte and Palaeonucula (VC), occasional Isocyprina, Nucinella, Corbulomima and Liostrea

M5 Clay, silty, dark, weathering light grey, fossiliferous; shell-bed $10 \mathrm{~cm}$ thick at base with large Liostrea, Palaeonucula (VC) and Grammatodon, and a tree trunk; first appearance of Nicaniella (Nicaniella)

$$
\text { - gradual colour change - }
$$

M6 Clay, silty, calcareous, weathering dark grey, shell content decreasing upwards. Bivalves well preserved: Thracia (VC), Grammatodon, Entolium, Nicaniella (C)

$$
\text { - passing into - }
$$

M7 Clay, silty, dark, weathering light grey, shelly, bivalves well preserved. Layer of large ammonites at base: Aulacostephanoides (M); Thracia and Palaeonucula (VC), Nicaniella, Grammatodon, Nucinella and Entolium (C)

M8 Pentacrinus Bed. Clay, silty, calcareous, weathering grey, moderately shelly with a diverse fauna, somewhat bioturbated in places with pyritic burrows; a shell-bed $0.20 \mathrm{~m}$ up, a horizon of Gervillella at $0.80 \mathrm{~m}$ and a horizon of Pinna at the top. Ammonites rare except near the top; fine-ribbed forms as before, the ribbing now perceptibly interrupted on the venter: Aulacostephanites eulepidus (Schneid). Pholadomya, Palaeonucula and Acteonina (VC); Corbulomima, Entolium and Liostrea (C); occasional Dacromya, Nanogyra, Lopha and Trigonia. Pentacrinoid fragments abundant in places, especially at $0.80 \mathrm{~m}$ up. Echinoid spines abundant at the top -intensely bioturbated boundary, Thallasinoides in uppermost $0.25 \mathrm{~m}$

M9 Clay, silty, calcareous, weathering light grey, shelly, well preserved fauna. Shell-bed of large Gervillella in patches at the base; the orientation of all specimens in one patch (N40) is shown in fig. 2, yielding a bimodal orientation. Grammatodon, juvenile Nicaniella, Thracia and Isocyprina (VC), Dacromya and Nanogyra. Ammonites rare: Amoeboceras (Amoebites) beaugrandi (Sauvage)

- passing into -

M10 Clay, silty, compact, dark, sparsely shelly at bottom, becoming more shelly at top with moderately to well preserved bivalves: Grammatodon, Nicaniella and Acteonina. A tree trunk at the top

M11 Serpula Bed. Clay, silty, compact, weathering light grey, moderately shelly, bivalves well preserved. Grammatodon (VC), occasional Palaeonucula, Thracia and Nanogyra. Abundant Serpula

M12 Clays, silty, compact, hard and shaly, roughly divisible into two parts:

(a) lower part dark; somewhat fissile band with ammonite plaster at $0.20 \mathrm{~m}$, profuse Aulacostephanites eulepidus (Schneid), microconchs only c. 1.50 (b) upper part lighter, moderately shelly, with layer of well-spaced large septarian concretions up to $0.50 \mathrm{~m}$ in diameter and $10 \mathrm{~m}$ apart near the bottom c. 0.80 Well-preserved bivalves throughout:

Grammatodon (VC), Thracia, Corbulomima and Gervillela, especially in the lower part. Occasional Deltoideum delta (Smith)

0.50 M13 Clay, silty, compact, dark, with scattered shells. Thracia (VC), Nicaniella, Palaeonucula and Nanogyra (C), Corbulomima; gastropods-'Aporrhais' (sensu de Loriol \& Pellat, 1874 , pl. 10 )

0.45 M14 Clay, silty, dark to medium grey, two slightly lighter bands in the lower part, moderately to very shelly, bivalves well preserved. Very 

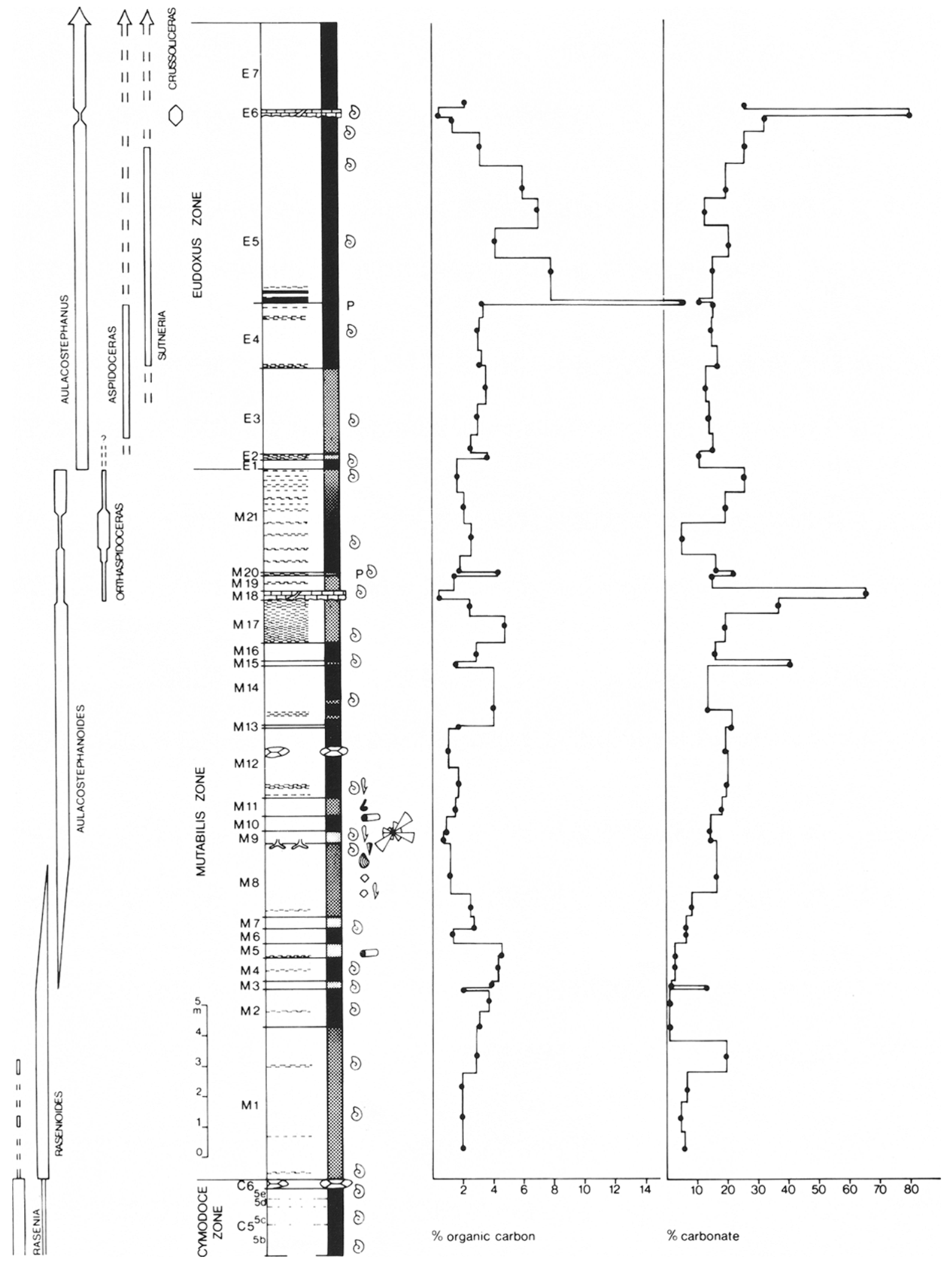
large macroconch ammonites throughout: Aulacostephanoides ex gr. mutabilis (J. de C. Sowerby); Lingula at the top. A shell-bed $0.30-0.50 \mathrm{~m}$ above the base; Thracia and Grammatodon (VC at the base), Nicaniella, Corbulomina, Isocyprina and Nanogyra (C), occasional Entolium. Chlamys and Palaeonucula

M15 Clay, silty, weathering light grey with sparse and poorly preserved shells: Thracia and Liostrea (VC), Nicaniella, Nanogyra (C); Lingula (C).

M16 Clay, black, hard, relatively sparsely fossiliferous, bivalves poorly preserved. An ammonite plaster $5 \mathrm{~cm}$ above the base

M17 Clay, silty, shaly calcareous, very hard, highly fissile, light grey, packed with shell detritus throughout but decreasing upwards; pyritic detrital beds about 0.30 and $0.70 \mathrm{~m}$ above base; lignite. Ammonite plasters in the lowest $10 \mathrm{~cm}$ : Aulacostephanoides (M) and Aulacostephanites $(\mathrm{m})$, well preserved, ribbing clearly interrupted on the venter. Bivalves poorly preserved: Nicaniella (VC) [Supracorallina Bed] occasional Thracia, Grammatodon, Corbulomima and Nanogyra; Lingula

$$
\text { - undulating boundary - }
$$

M18 Marker: Mutabilis Limestone. Discontinuous lenticular limestone in light grey calcareous clay. A layer of large, typical Aulacostephanoides muabilis (M), up to $300 \mathrm{~mm}$ diameter, evolute; Aspidoceras (Orthaspidoceras) sp; Nicaniella (C), Nanogyra (R)

$$
\text { - passing into - }
$$

M19 Clay, silty, calcareous, light, sparsely shelly except for a hard shelly layer between 0.30 and $0.40 \mathrm{~m}$ up, the shells moderately to well preserved. Entolium, Isocyprina (VC), Corbulomima and Nanogyra (C); Au. eulepidus
M20 Pyritic shell bed. Lower part highly bituminous, packed with shell debris, passing upwards into an ammonite plaster heavily encrusted with concretionary pyrite. Profuse large Liostrea below, in and above the bed. Aulacostephanites desmonotus, eulepidus and cf. mutabilis; Orthaspidoceras orthocera (d'Or0.95 bigny) $(\mathrm{M}) \&(\mathrm{~m})(\mathrm{C})$, including juveniles; Laevaptychus $(\mathrm{M}) \&(\mathrm{~m})(\mathrm{C})$, very delicate and thin-shelled calcareous upwards; well bedided but nonlaminated, sparsely shelly in the lower part with several detrital shell beds $0.10-0.20 \mathrm{~m}$ thick, showing signs of current transport. The top metre highly fossiliferous with much broken shell material, terminating with another detrital shell bed $0.10 \mathrm{~m}$ thick. Ammonites profuse to the top, at times in patches of plasters, including Aulacostephanoides ex gr. mutabilis (cf. attenuatus Ziegler) (M), large evolute complete adults found within a few $\mathrm{cm}$ of the top, and $A$. linealis (Quenstedt); Aulacostephanites desmonotus (Oppel) and eulepidus (Schneid); Orthaspidoceras orthocera (d'Orbigny) and its Laevaptychus, scattered throughout but concentrated particularly in a bed $1.20 \mathrm{~m}$ up. Nanogyra (VC), including the large denselyribbed forms of $N$. virgula (Defrance) prominent during mapping, Palaeonucula (C), Thracia, Entolium, Oxytoma; Lingula; Serpula (C); "Aporrhais"

-burrow-mottled transition: darker clays from above burrowed into the lighter clays below to a depth of up to $10 \mathrm{~cm}$

Eudoxus Zone

E1 Clay, silty, shaly and somewhat fissile, darker than below and rather less fossiliferous, many shells broken, densely shell-detritic about $0.10 \mathrm{~m}$ up. Aulacostephanus eudoxus (d'Orbigny) typical, including complete adult macroconchs up to $300 \mathrm{~mm}$ diameter, the first $2 \mathrm{~cm}$ above the base, $A u$. cf. attenuatus (Ziegler) (M); fine-ribbed forms like Aulacostephanoides in the beds below totally absent. Large Liostrea, Lingula (C)

E2 Shell bed: very hard clay, silty, much fossil detritus. Au. eudoxus (M) \& (m) (C), Aspidoceras longispinum (J. de C. Sowerby) (M) sensu lato, and $\mathrm{sp}$. (m), with small Laevaptychus (VC); Liostrea, Nanogyra, Thracia, Nicaniella, Isocyprina (VC); Rhynchonelloidella, Lingula

E3 Clay, silty, somewhat laminated and shaly, sparsely to moderately shelly, the shells poorly preserved. Aulacostephanus eudoxus (d'Orb.), Au. pseudomutabilis (de Loriol), Aspidoceras and Laevaptychus; Liostrea, Nanogyra, Isocyprina, Thracia, Nicaniella; Lingula

E4 Clay, silty, dark, shelly throughout but most shells broken; two detrital shell horizons, the lower, hard, at the base, the upper $1.60 \mathrm{~m}$ up. Aulacostephanus eudoxus, Sutneria eumela

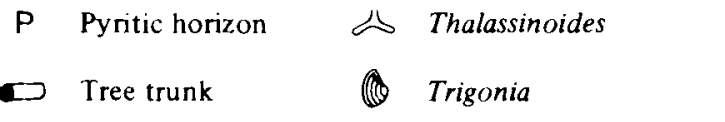


(d'Orbigny), Amoeboceras (Amoebites) aff. elegans Spath (R), small Laevaptychus; Nanogyra virgula, Isocyprina, Palaeonucula (VC). Protocardia common in top part, horizon of Liostrea $0.15 \mathrm{~m}$ below top

$$
\text { - sharp boundary - }
$$

E5 Shales, laminated, dark, weathering greybrown, fissile paper-shales at some levels, moderately to highly bituminous. Divisible into smaller units:

(a) At base, marker, lithified oil-shale, $0.10 \mathrm{~m}$, passing into homogeneous dark organic-rich shale, $0.10 \mathrm{~m}$;

(b) Clay, soft, light, fossiliferous, with sharp boundaries, $0.10 \mathrm{~m}$;

(c) Shale, hard, less fissile than (a), bituminous $0.20 \mathrm{~m}$;

(d) Clay, soft, fossiliferous, c. $0.10 \mathrm{~m}$,

(e) Shales, etc. In the rest of the bed the shell content increases upwards and the organic content decreases. Poorly preserved Nanogyra profuse in the upper half of the bed, the top $0.20 \mathrm{~m}$ packed. Aulacostephanus eudoxus near the top, Sutneria eumela at certain levels, very large Aspidoceras ex gr. acanthicum (Oppel) scattered throughout, occasional Amoeboceras (Nannocardioceras). Protocardia and Lingula are nearly the only fossils in the oil-shale; at other levels, Protocardia, Entolium (VC), Palaeonucula, Spinigera (C), Liostrea (R); Serpula (C) at certain horizons. Many horizons densely spotted with foraminifera. A large skull and jaw of Pliosaurus sp. found $1 \mathrm{~m}$ below the top (now in Bristol City Museum)

$$
\text { - undulating boundary - }
$$

E6 Marker: Crussoliceras Limestone. Highly calcareous shale, light grey, hardened locally into lenticular or concretionary limestone, crumbly and much shattered by compaction. Few fossils besides Nanogyra. Aulacostephanus eudoxus (R), and perisphinctids, fairly common but mostly fragmentary: Crussoliceras cf. atavum (Schneid) and cf. sevogodense (Contini \& Hantzpergue) (M \& $\mathrm{m}$ ) [= the Virgula Limestone or 'Propectinatites' Band of Gallois \& Cox]

E7 Clays, laminated, or shales, dark, fissile, as below, continued, lower part still rich in Nanogyra, seen to

end of section; topsoil

\section{(b) Notes on the ammonites (JHC) (see Figs. 3-6)}

(1) Rasenia-Aulacostephanus. Much new stratigraphical information obtained since these genera were last extensively discussed (Geyer, 1961; Ziegler, 1962; Arkell \& Callomon, 1963) makes it necessary to revise our views of their interrelationships.

The faunal sequence in the Lower Kimmeridgian of England could be divided into five successive groups which were made the basis of Salfeld's zonal classification. From below:

I. Forms with perisphinctid ribbing but heavily collared and flared constrictions: Pictonia Salfeld (Baylei Zone).

II. Forms still with flared constrictions of Pictonia but developing coarse bullate primary ribbing dividing into fasciculate sheaves of secondaries: Rasenia Salfeld (Cymodoce Zone).

III. Forms with dense and fine fasciculate ribbing passing over the venter without weakening: 'late fine-ribbed Rasenia' including Rasenioides Schindewolf (lower Mutabilis Zone).

IV. Forms with dense and fine fasciculate ribbing, as in III, but now interrupted on the venter to give a smooth band: 'early fine-ribbed Aulacostephanus', including Aulacostephanoides Schindewolf (upper Mutabilis Zone).

V. Forms with strong, coarse, straight, nonfasciculate ribbing terminating abruptly on the sharp angular margins of a flat or grooved tabulate venter; Aulacostephanus (olim Pseudomutabilis Zone, now Eudoxus and Autissiodorensis Zone).

The faunas appeared to be mutually exclusive, i.e. non-overlapping, but each retained enough of the characters of its predecessors to suggest that they formed an evolutionary sequence. The phyletic development of the characteristic ventral smooth band was thought to be particularly significant, and so the boundary between Rasenia and Aulacostephanus was drawn between III and IV, in the middle of the 'fine-ribbed rasenids' of the Mutabilis Zone. What was not clear was the nature of the boundaries between groups II and III, and IV and V, i.e. the faunal changes at the boundaries of the Mutabilis Zone as a whole. These are now revealed at Westbury.

The forms of Rasenia in the upper Cymodoce Zone were already summarized on a previous occasion (Birkelund et al., 1978). They consist predominantly of the two species made famous through the old collections from Market Rasen, Rasenia involuta Spath (type species of the genus) and $R$. evoluta Spath. Further collecting at Westbury confirms the previous conclusions that, making allowance for crushing, the range of forms found in bed C5(e) is identical with that of $R$. evoluta from Market Rasen in both dimorphs. The fauna from slightly lower, C5(c) contains some variants resembling $R$. involuta, but the

Fig. 3. Ammonites of the Cymodoce Zone

A Rasenia involuta Spath transitional to $R$. evoluta Spath [M]. Plaster cast of only partly crushed, almost complete adult.

B Rasenia involuta Spath [m]. Fine-ribbed variant, with three quarters whorl bodychamber.

C Rasenia involuta Spath [m]. Typical, with lappet.

$\mathrm{D}$ Rasenia involuta Spath [m]. Variant with evolute bodychamber, parts of terminal constriction and stump of lappet preserved. Westbury, bed C5(c), natural size. 


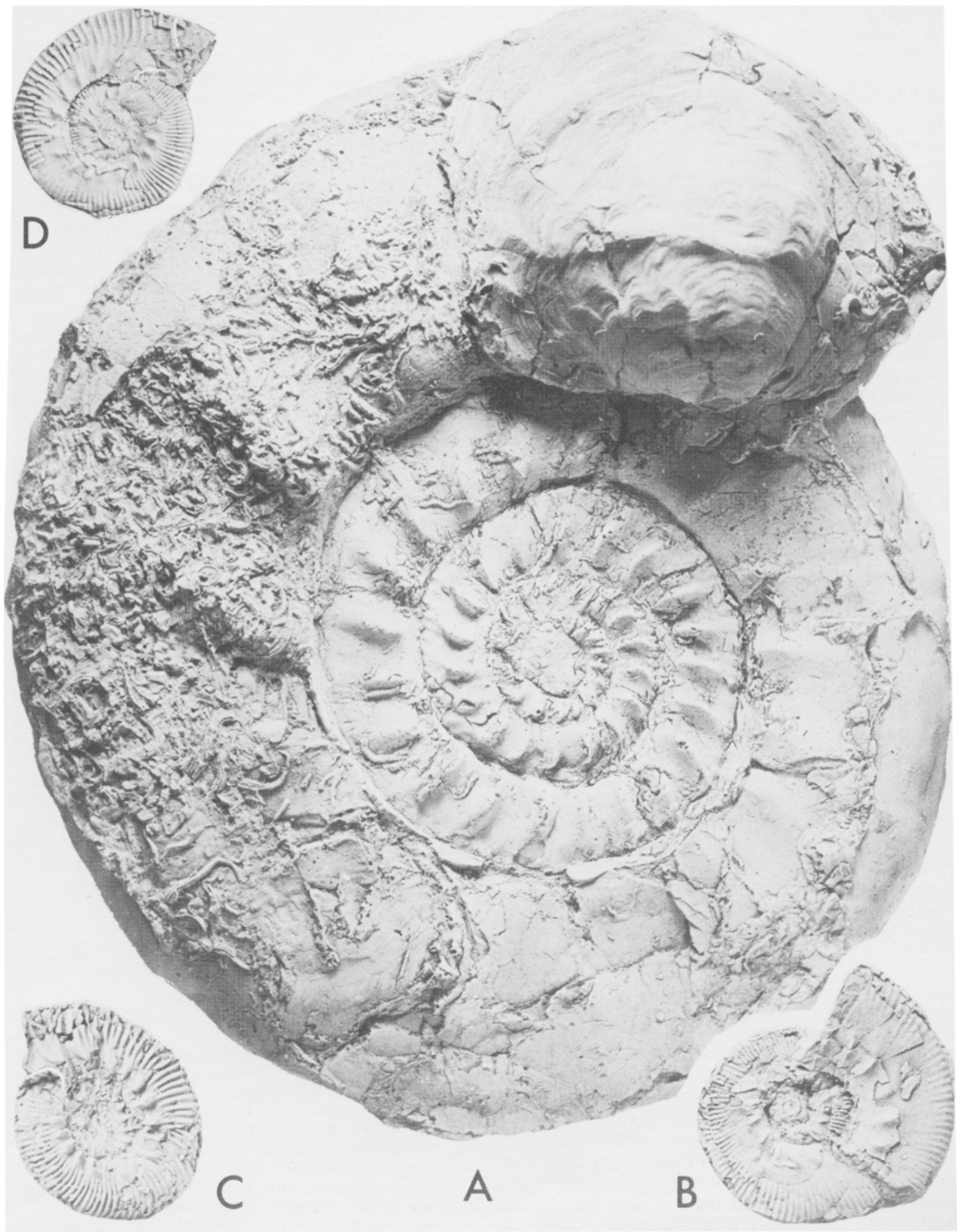


assemblage as a whole is not quite the same: it seems intermediate between $R$. involuta and $R$. evoluta.

These upper beds of the Cymodoce Zone also already contain representatives of the fine-ribbed rasenids that dominate in the Mutabilis Zone. They are relatively rare and distinct from $R$. evoluta, but differ little from those above. It seems therefore that the fine-ribbed forms and Rasenia were already following separate evolutionary paths before the top of the Cymodoce Zone and they can now be separated generically; the name Rasenioides Schindewolf is available for the fine-ribbed forms (type $R$. striolaris (Reinecke)). The transition from group II to group III is sharp, occurring at Westbury within a span of at most $30 \mathrm{~cm}$, but it reflects a sudden change in relative proportions of the two faunas rather than their lineal succession. The transition appears to be equally sharp elsewhere in England (Gallois \& Cox, 1976; Cox \& Gallois, 1981), and makes a fine basis for the boundary between Cymodoce and Mutabilis Zones. Further afield it may be more difficult to recognize. Rasenia s.s. for instance never colonized southern Germany, the type-area of Rasenioides, or the Jura, its place being taken there by other groups that in turn are unknown in Britain. The Cymodoce Zone cannot therefore be recognized there as such. The Mutabilis Zone did not however see the end of the Rasenia line: the discovery of two specimens in bed M1 at Westbury indicates that it lingered on. It had probably merely migrated further into the Boreal Realm.

(2) Xenostephanus. In addition to the groups II-V discussed above, there were some others that were hard to place, in particular one from glacial boulders in Lincolnshire. It had already most of the morphological characters of group $\mathrm{V}$, including the non-fasciculate secondary ribbing and the ventral smooth band or groove, but the associated fauna pointed to a much lower level, equivalent to group III somewhere in the lower Mutabilis Zone. It was given the name Xenostephanus (Arkell \& Callomon, 1963). The fauna was subsequently found in situ in the Elsham Sandstone, an arenaceous local facies of the Kimmeridge Clay in northern Lincolnshire, but no adjacent faunas could be seen so that no independent evidence of its position in the sequence was forthcoming. The genus was subsequently reported as widespread in southern England, marking a 'Xenostephanus horizon' still incorporated in the Cymodoce Zone (Gallois \& Cox, 1976).

The 'Xenostephanus horizon', if present at Westbury, would have to be identified there with bed C5(e), the horizon of $R$. evoluta. This horizon is not the same as the Xenostephanus horizon that yielded the type material $(X$. ranbyensis Arkell \& Callomon (M) and $X$. thurrelli (Arkell \& Callomon) (m)), in the Elsham Sandstone. In the boreholes around the Wash, where the 'Xenostephanus horizon' was first defined (Gallois \& Cox 1976, bed 12) Xenostephanus is recorded as a constituent of a fauna containing also both ordinary Rasenia of the group of $R$. evoluta, and Rasenioides. In the Elsham Sandstone Rasenia s.s. is very rare and the dominant component of the fauna is Rasenioides at the stage of its evolution about half-way between the forms with and without ventral interruption of the ribbing: variants with and without ventral smooth band occurred together in the same block. This indicates a level equivalent to something between beds M3 and M8 at Westbury, well above the Cymodoce Zone but still well down in the Mutabilis Zone, far below true Aulacostephanus of the Eudoxus Zone. A similar fauna of Xenostephanus s.s. has since been described from northern Siberia (Mesezhnikov, 1969) and it appears to occur at a similar horizon. The position of Xenostephanus reported around the Wash in eastern England could therefore have several interpretations. Firstly, some of the specimens recorded as Xenostephanus could have been misidentified, for we have repeatedly found variants of microconch $R$. evoluta at Westbury that, when crushed, certainly have a strong resemblance to microconch Xenostephanus s.s. and to the equally crushed specimens figured by Gallois \& Cox (1976, pl.3), particularly in the adult bodychamber. They could however be distinguished by comparing the inner whorls, those of Rasenia retaining the characteristic bullate, primary ribs and fasciculate secondaries in contrast to the coarse bi-or trifurcate secondaries exposed in the umbilicus of Xenostephanus. We found none at Westbury with ventral smooth band, although occasional uncrushed specimens in the museums from Market Rasen do show signs of incipient ventral grooves while otherwise retaining all the characters of $R$. evoluta. Secondly, it could be that forms with the generic characters of Xenostephanus range lower in eastern England, into the top of the Cymodoce Zone, than they do at Westbury. This would imply provincial differentiation between Norfolk and Wiltshire of Rasenia s.s. and these early forms resembling Xenostephanus. This would not be surprising, for the subsequent distribution of

Fig. 4. Ammonites of the Cymodoce Zone

A Rasenia involuta Spath [M]. Complete, feebly-ribbed adult, x 0.5 . Westbury, bed $\mathrm{C} 5$ (c)

B Rasenia involuta Spath transitional to $R$. evoluta Spath [M]. Plaster cast of complete adult with strongly and densely ribbed inner whorls. $x 0.5$, bed $\mathrm{C} 5(\mathrm{c})$

C,D Rasenia evoluta Spath [m]. Bodychamber fragment and almost complete adult of coarsely-ribbed variants, natural size; bed C5(e)

E Rasenia evoluta Spath [M]. Some at least of the outer whorl is bodychamber; note the variocostate modification of the ribbing on the last quarter whorl. Natural size, bed C5(e). 

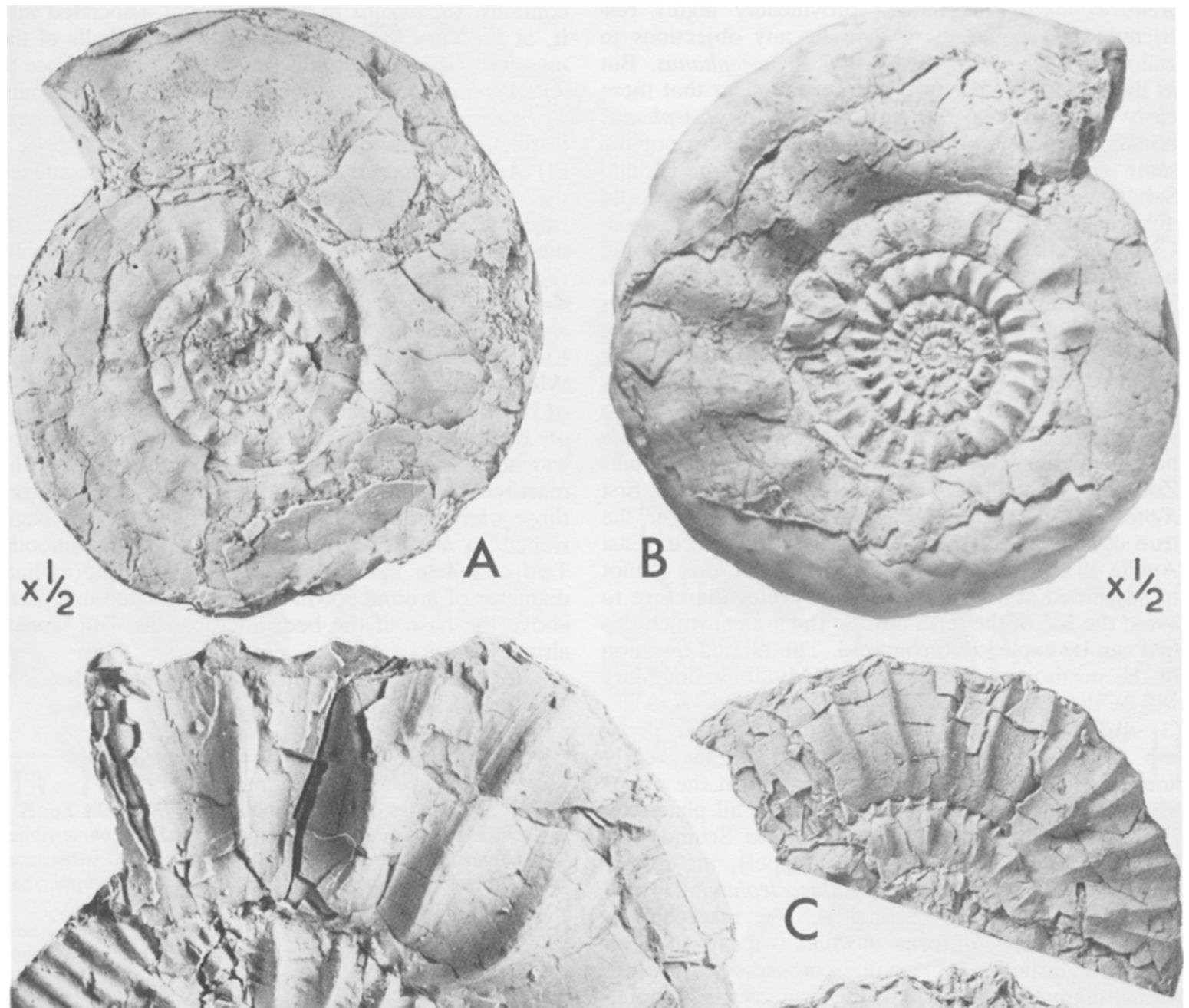

a 10.

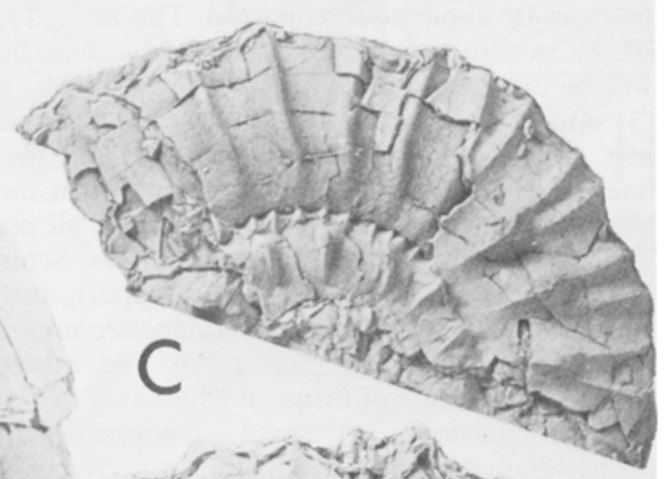

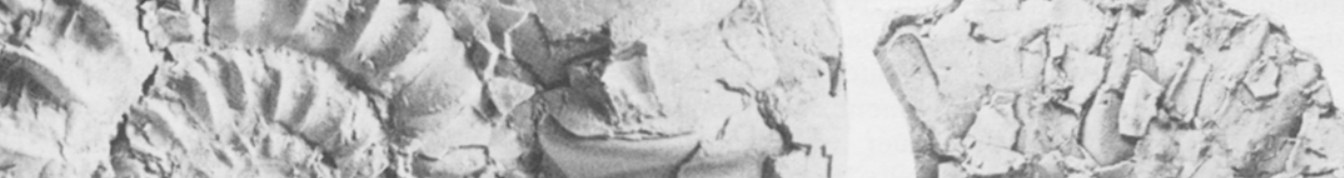

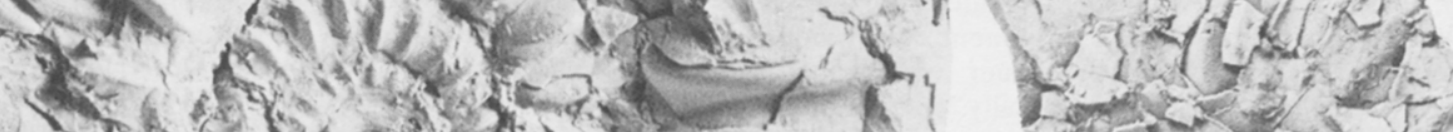

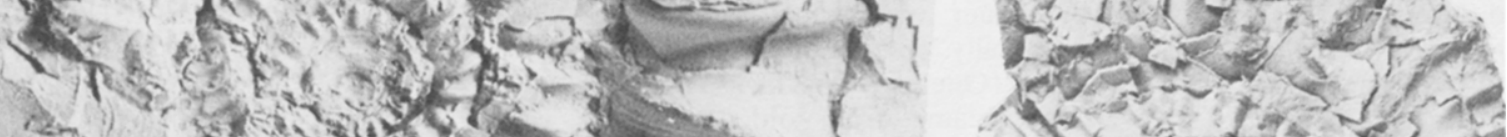

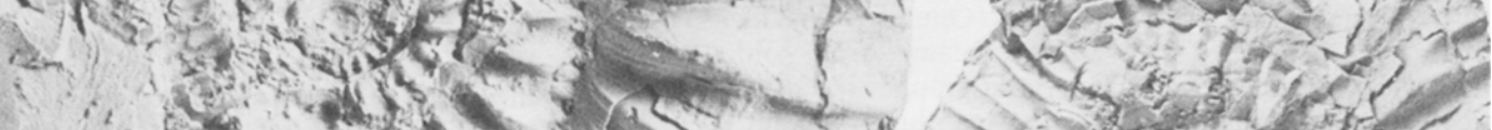

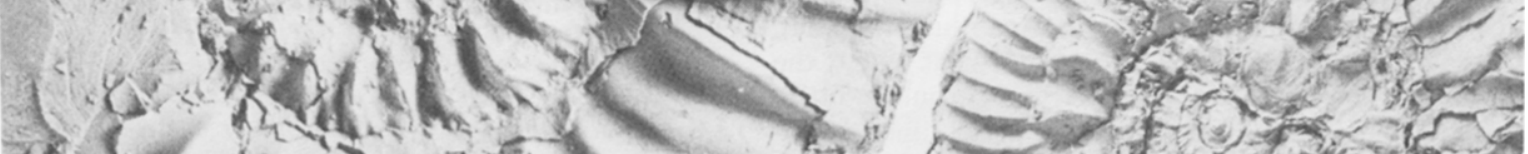

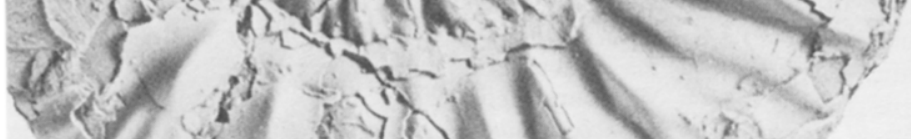
E

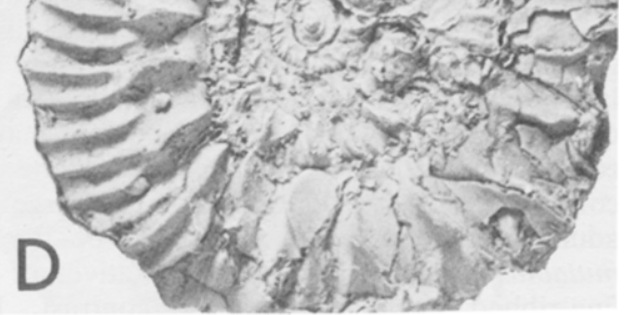


Xenostephanus was indeed provincially highly restricted. Nor would there then be any objections to calling these early forms already Xenostephanus. But in that case it would have to be made clear that these early forms of Xenostephanus, in the 'Xenostephanus horizon' in the upper Cymodoce Zone, were not the same as the Xenostephanus s.s. in the Elsham Sandstone of the Mutabilis Zone. The genus would now be interpreted as covering a range of forms, from Cymodoce to Mutabilis Zones; but then there would be more than just 'the' Xenostephanus horizon. Thirdly, Gallois \& Cox's bed 12 in eastern England is stated to have a thickness of $3.7 \mathrm{~m}$. It might therefore be composite: different parts might carry different faunas. With the Cymodoce-Mutabilis boundary as taken at Westbury somewhere in the middle, there would be plenty of room both for the Rasenia evoluta horizon in the lower part and enough of the Mutabilis Zone in the upper part to bring in the first Xenostephanus, within the same bed. Whatever the true case may be, the 'Xenostephanus beds' of East Anglia as defined by bed 12 of Gallois \& Cox cannot be identified at Westbury, and we prefer therefore to avoid the use of the term outside the area in which this bed can be explicitly recognized. The related question of the position of the Cymodoce-Mutabilis boundary will be discussed again below.

(3) Aulacostephanoides Schindewolf. Another problem remaining to be resolved lies in the "early fine-ribbed Aulacostephanus', group IV, in the upper Mutabilis Zone. The macroconchs were all placed by Ziegler (1962) into Aulacostephanoides Schindewolf (type species Amm. desmonotus Oppel), the microconchs in a new subgenus Aulacostephanites (type species $A u$. eulepidus (Schneid)). The macroconchs cover a wide range of forms in which two extremes can be distinguished: (a) small, compressed involute forms, diameter $80-150 \mathrm{~mm}$, the primary ribs tending to fade: Au. desmonotus (Oppel), linealis (Quenstedt); (b) large, evolute planulates, diameter $200-300 \mathrm{~mm}$, the primaries prominent and welldifferentiated, at least on the inner whorls; $A u$. mutabilis (Sowerby). Morphologically intermediate forms include $A u$. circumplicatus (Quenstedt). The material seen by Ziegler chiefly came from old museum collections with little stratigraphic information beyond 'Mutabilis Zone' or 'Acanthicum Zone', so that it was impossible to decide to what extent the morphological diversity reflected synchronous intraspecific variability on the one hand and stratigraphically successive stages on the other; and if the latter, what the correct sequences are. All the forms occur at Westbury and the relationships may be quite complicated. Thus the Mutabilis Limestone, bed M18, contains a sharply-defined layer of large complete adult macroconchs that appear to be the true $A u$. mutabilis itself, with no representatives of the small fine-ribbed linealis group. In contrast, bed M21 contains $A u$. linealis in profusion, but associated with it, at the very top, are occasional large shells of the mutabilis group, very feebly ribbed and hence close to Au. attenuatus Ziegler. The impression that the groups of $A u$. mutabilis and $A u$. linealis may represent distinct parallel lineages needs further investigation.

(4) Aulacostephanus sensu stricto. We have examined the boundary between beds M21 and E1 very carefully, and the faunal break is absolute. The fine-ribbed forms of the linealis group are wholly replaced by the coarse and straight-ribbed Aulacostephanus eudoxus (d'Orbigny) (m), variants that closely resemble one figured by Ziegler from the lower Eudoxus Zone of Swabia (1962, pl. 5, fig. 24; levels White Jura 83 ). Fragments could be found in the infill of burrows descending as much as $10 \mathrm{~cm}$ into the top of bed M21 below, but not a single undoubted fragment of $A u$. linealis was found in E1. The macroconchs have inner whorls indistinguishable from those of the microconchs; they are evolute, strongly ribbed to about $100 \mathrm{~mm}$ and then become smooth. Two complete adults with simple peristome at final diameter of around $300 \mathrm{~mm}$ were excavated only $2 \mathrm{~cm}$ above the base of the bed; microconchs with lappets also occurred.

The observations confirm previous indications

Fig. 5. Ammonites of the Cymodoce and Mutabilis Zones

A-C Rasenia evoluta Spath [m]. A,B, coarse-ribbed Xenostephanus-like variants; $\mathrm{C}$, variant with more subdued ribbing. Westbury, bed $\mathrm{C} 5(\mathrm{e})$, uppermost Cymodoce Zone.

D,E Rasenioides cf. lepidulus (Oppel) [m]. Complete adults with lappets. Westbury, bed M1, lower half, Mutabilis Zone, horizons with $R$. askepta.

F,G Aulacostephanoides eulepidus (Schneid) [m]. F, complete adult with lappet, natural size; $G$, fragment embedded vertically showing the smooth band interrupting the ribbing on the venter, $\mathrm{x} 3$.

H Aulacostephanoides cf. desmonotus (Oppel) [m]. Found beside $\mathrm{F}$ on the same bedding -plane and probably only the fine-ribbed involute end-member in the range of variability of the same species. Westbury, Mutabilis Zone, bed M8, near the top.

I Aulacostephanoides mutabilis (J. Sowerby) [M]. Inner whorls, wholly septate, of a large evolute shell becoming wholly smooth on the outer whorls. Westbury, Mutabilis Zone, bed M18.

J,K Aulacostephanoides cf. desmonotus (Oppel) [m]. Note the interruption of the ribbing on the venter. Westbury, bed M20.

L,M Aulacostephanoides linealis (Quenstedt, 1888, non Link, 1807, nec Schlotheim, 1820)-Ziegler, 1962. L: [M], bed $20 ; \mathrm{M}:[\mathrm{m}]$, with lappet, bed $\mathrm{M} 21$, top $10 \mathrm{~cm}$. Westbury, upper Mutabilis Zone.

N Aulacostephanoides cf. desmonotus (Oppel) or eulepidus (Schneid) [m]. Small adult with lappet. Westbury, topmost Mutabilis Zone, bed M21, top $10 \mathrm{~cm}$. 


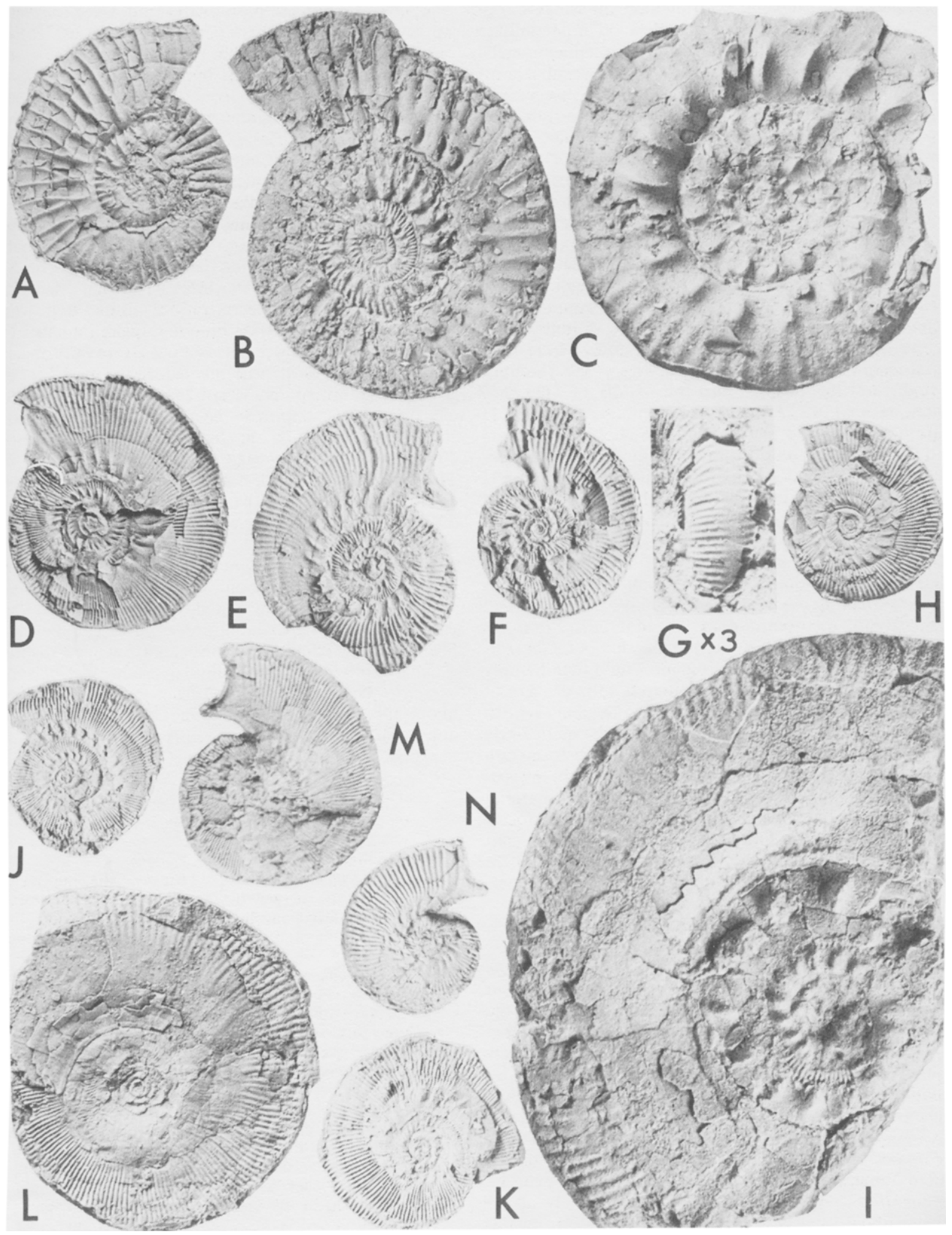


elsewhere in England: Warlingham; Wash, base of bed 26; Dorset (see Appendix). The boundary between Mutabilis and Eudoxus Zones appears to be marked everywhere over this area by an almost equally sharp break in the ammonite succession, giving the impression of an abrupt faunal transgression. The phyletic relationships between the groups immediately below and above the break are unclear. (5) Aspidoceras. The first Aspidoceras appears in the Mutabilis Limestone, bed M18, in which it is relatively common. This is between 4.0 and $4.3 \mathrm{~m}$ below the top of the Mutabilis Zone. The forms have a single row of well-spaced lateral tubercles, characteristic of $A$. (Orthaspidoceras). They are relatively small and the tubercles are low on the whorl-side, suggesting $A$. $(O$. lallierianum (d'Orbigny), but the preservation was not good enough for closer identification. These unituberculate forms range up to the top of the Mutabilis Zone, and in bed M20 and the middle of M21 they may even be the dominant ammonite. Those in M21 are now large and include the true $A$. $(O$.$) orthocera$ (d'Orbigny). Aspidoceratids, including Orthaspidoceras, were equally common in the top $4 \mathrm{~m}$ of the Mutabilis Zone in the Warlingham borehole. In contrast, in the Wash boreholes Aspidoceras is said to commence only above the base of the Eudoxus Zone (Gallois \& Cox, 1976), in bed 24; but this statement depends on the definition of the base of the Eudoxus Zone, which is discussed again below. If beds 24 and 25 are still incorporated in the Mutabilis Zone the discrepancy disappears, although the Aspidocerasbearing part of the Mutabilis Zone would then be only $1.75 \mathrm{~m}$ thick in the Wash, compared with the $4 \mathrm{~m}$ at Westbury and at Warlingham.

The aspidoceratids continue upwards abundantly into the Eudoxus Zone, as elsewhere. The forms are now evolute and bituberculate-Aspidoceras longispinum (Sowerby, 1825) sensu lato-but better material would be needed to distinguish closely-related forms widely cited in the literature, such as $A$. acanthicum (Oppel, 1863) (lectotype figured by Neumayr, 1873, pl. 41), A. caletanum (Oppel, 1863) $(=A$. longispinum d'Orbigny, 1850 , pl. 209, non Sowerby), $A$. liparum (Oppel, 1863), or A. catalaunicum (de Loriol, 1872) (see Contini \& Hantzpergue, 1975).

(6) Crussoliceras Enay, 1959 ('Propectinatites'). One of the discoveries by Gallois \& Cox during their exploration of the lower Kimmeridge Clay was the presence everywhere of a 0.5 metre calcareous bed in the Eudoxus Zone yielding almost exclusively perisphinctid ammonites in the middle of an otherwise almost unbroken succession of aulacostephanitids. They identified these forms with the genus Propectinatites Cope, 1968, and labelled the bed the 'Propectinatites Band' (1976, bed 30, middle part, ca $18 \mathrm{~m}$ above the base of the Eudoxus Zone). It can be recognized on the Dorset Coast, immediately above the 'Virgula Limestone' (Cox \& Gallois, 1981, figs. 2,
5, 25-60 $\mathrm{m}$ above the base of the Eudoxus Zone) and apparently at Warlingham (Callomon, 1971, p. 161, at $-2755 \mathrm{ft}, 50 \mathrm{~m}$ above the base of the Zone). At Westbury it is represented by bed E6, $11.5 \mathrm{~m}$ above the base of the Eudoxus Zone. The material from all these localities is fragmentary, but it is the same as that from the old clay-pits around Ely now in the Sedgwick Museum, Cambridge. The 'Propectinatites Band' may still be seen in the pit at Roslyn Hill (TL $550886,1 \mathrm{~km}$ ENE of Ely cathedral) as a calcareous clay with septarian concretions near the top, bed 2 in the description by Roberts (1892, p. 66), and yields fragmentary perisphinctids recorded by Roberts as 'Am. biplex' just as at Westbury. The same bed was also formerly exposed $3 \mathrm{~km} \mathrm{~N}$ in a pit at Chettisham station (Roberts, p. 70), where it yielded a number of well-preserved macroconchs up to $220 \mathrm{~mm}$ in diameter (e.g. Sedgwick J59855-6) that allow the fauna to be precisely identified. These specimens are very close to the types of Perisphinctes atavus Schneid (1915, p. 94, pl. 2, fig. 2, pl. 9, fig. 1), from the Eudoxus Zone of Franconia; and Katroliceras sevogodensis Contini \& Hantzpergue, 1975 (p. 12, pl. 4, fig. 4), from the Eudoxus Zone of Savoyeux, Hte Saône, 'Marnes à Exogyres (sic)', horizon with Aulacostephanus contejeani (Thurmann).

Either could be combined with the Ely specimens within what would be an entirely usual range of intraspecific perisphinctid variability, and in all essential features of coiling and style of ribbing they are identical. They differ consistently from a slightly older but otherwise not dissimilar group, Katroliceras aceroides Geyer, 1961 (p. 41) from the equivalents of about the lower Mutabilis Zone sensu anglico. The appropriate generic name presents some problems, for the one popularly used for this group, Katoliceras

Fig. 6. Ammonites of the Eudoxus Zone

A Aulacostephanus eudoxus (d'Orbigny) [M]. Imprint of inner whorls of a large complete adult $320 \mathrm{~mm}$ in diameter, becoming wholly smooth at ca. $100 \mathrm{~mm}$. Westbury, basal Eudoxus Zone. bed E1, $5 \mathrm{~cm}$ above the base.

B,C Aulacostephanus eudoxus (d'Orbigny) [m]. B: Westbury, bed E1, lowest $10 \mathrm{~cm}$; C: complete adult with lappet, Osmington Mills, Dorset, $1.6 \mathrm{~m}$ above the Osmington Mills Siltstone, $=0.9 \mathrm{~m}$ above the base of the Eudoxus Zone.

D Aulacostephanus eudoxus transitional to Au. pseudomutabilis (de Loriol) [m?]. Westbury, bed E2.

E Aulacostephanus pseudomutabilis (de Loriol) [m]. At least two thirds of the outer whorl is bodychamber. Westbury, bed E5, base.

F, G Sutneria eumela (d'Orbigny) $[\mathrm{m}] . F^{\prime}, \mathrm{G}^{\prime}, \mathrm{x} 2$. Westbury, bed E5(a). Clearly microconchs, the corresponding macroconchs of this genus continue to defy identification. 


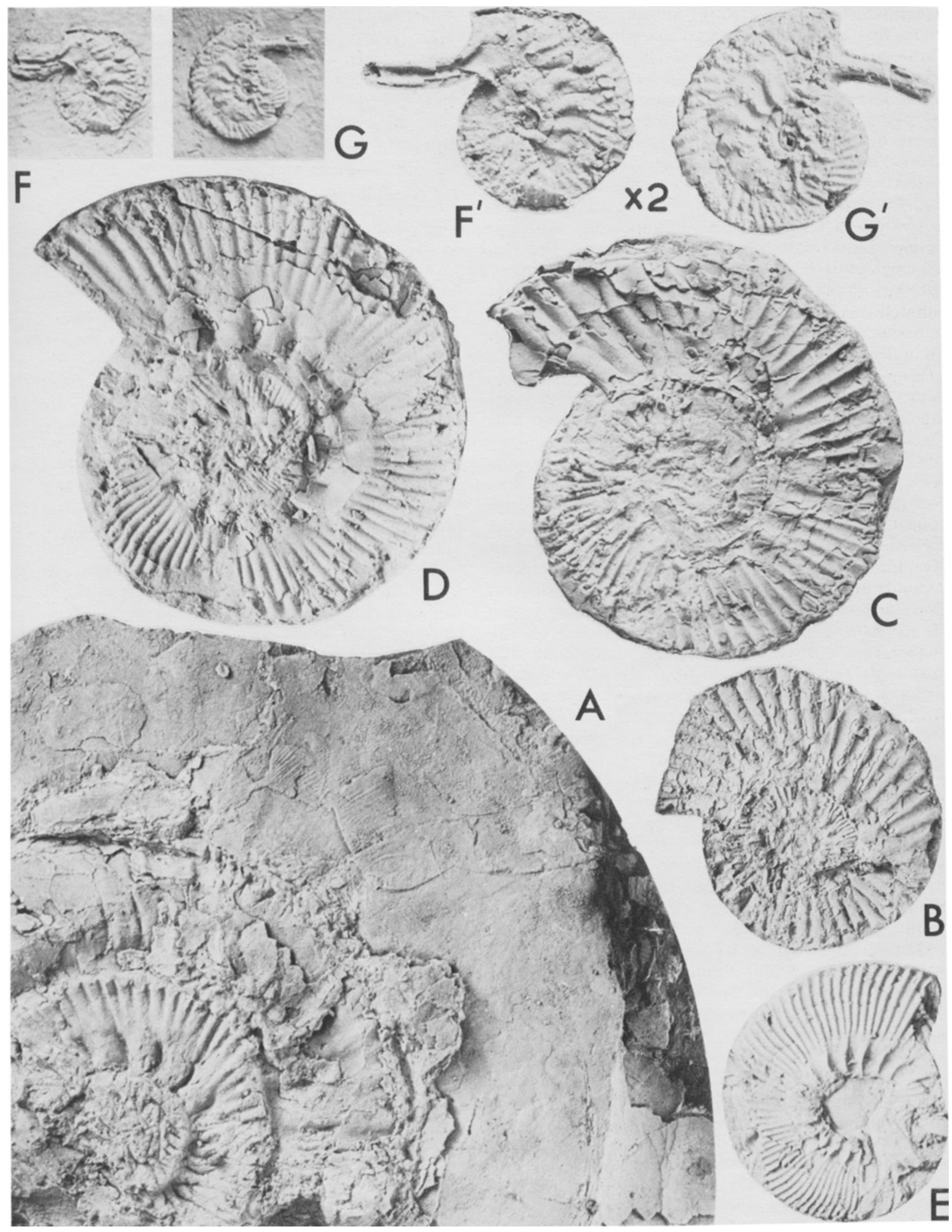


Spath, 1924, was founded for faunas from Kenya and India that are rather younger and whose relations to those of Europe remain to be established. It is safer to use the European name Crussoliceras Enay, 1959 (p. 229). The macroconchs are accompanied at Westbury by plentiful fragments of simply biplicate, isocostate microconchs resembling Am. lacertosus Fontannes (1876) from the same slightly older levels as Crussoliceras aceroides, but matching material from the Eudoxus Zone appears not yet to have been described. The commonest localities for all these perisphinctids is in the sub-Mediterranean Province (Spain, southern France, Jura, southern Germany, southern Poland, Balkans) and their presence at one isolated level in England represents a brief excursion into the sub-Boreal Province otherwise inhabited by the aulacostephanitids.

Propectinatites Cope (1968, type species $P$. websteri) is considerably different. It was founded for what are the first members of a new Boreal lineage, the Pectinatitinae, that includes the genus Pectinatites Buckman, 1922. The macroconchs of Propectinatites are more densely and irregularly ribbed than Crussoliceras, as in Pectinatites. These early forms appear suddenly in quantity in the upper part of the Autissiodorensis Zone, displacing the aulacostephanitids at the top of zone, and the lineage then continues upwards without interruption as the dominant element of the ammonite faunas in Britain into the Portlandian. They can be readily collected on the Dorset coast, whence came the type material, and their early ranges were seen also in the Warlingham borehole and on the Yorkshire coast (Callomon 1971, p. 161-162). There are however further complications. The levels that yielded the type material of Propectinatites include also the type-horizon of the genus Subdichotomoceras Spath, 1925 (p. 119). The type species of the latter, S. lamplughi Spath, has a microconch holotype (refigured by Arkell, 1957, p. L328, fig. 422) that came from the upper Autissiodorensis Zone of Speeton Bay, Yorkshire (referred to as Eudoxus Zone by Spath, but this in a wide sense before the 'Aulacostephanus Zone' had been subdivided: the Eudoxus Zone in the modern restricted sense does not crop out of Speeton). It is uncrushed and lacks the test, but it differs little from the crushed microconch paratype of Propectinatites websteri Cope (1968, pl. 1, fig. 1), which retains the shell. An uncrushed macroconch has been figured by Sheppard (1907, p. 277), holotype of Subdichotomoceras speetonensis Spath, 1925 (p. 210; lost by bombing during the last war), and although perhaps more evolute and more densely ribbed than the macroconch holotype of $P$. websteri, it too has the characters essentially of the Pectinatitinae rather than of Crussoliceras. Questions of specific identity apart, there seems little reason for retaining the genus Propectinatites distinct from what would seem to be its senior subjective synonym, Subdichotomoceras.

To retain a special name for the beds with Crussoliceras would be useful because of its great value as a marker for correlations, and we propose that it should be called the Crussoliceras Band and that all references to Propectinatites should be dropped.

\section{(c) Notes on non-ammonoid fossil markers}

Peak occurrences of a number of non-ammonoid fossils are widely used as stratigraphical markers in the Lower Kimmeridge Clay, e.g. in the Nana Beds, Virgula Limestone, Deltoideum delta Beds, Supracorallina Bed, and the Pentacrinus and Saccocoma Bands. The occurrence of these fossils at Westbury is discussed below.

(1) Nanogyra. The Jurassic Nanogyra was separated from the Cretaceous Exogyra by Beurlen (1958). Cox pointed out in 1930 that the name Exogyra virgula (Defrance, 1821-31) is a junior synonym of $E$. striata (W. Smith, 1817), but Arkell (1933, p. 440, footnote 9) proposed retention of the name $E$. virgula as it has become firmly established in the literature. This proposal has been upheld in ICZN Opinion 310 (1954).

According to Ziegler (1969), Nanogyra virgula evolved from $N$. nana in the upper part of the Baylei Zone. In younger parts of the Kimmeridge clay the two are rarely found together in Britain. This is the case at Westbury where $N$. virgula is dominant, occurring in large numbers in certain layers from M1 upwards, particularly so in E5 and E7. In the Aquitaine Basin $N$. virgula becomes the dominant species at a similar level, in horizons XV-XVI (equivalent to the lower part of the Mutabilis Zone as here understood-see table 1) (Gautret \& Hantzpergue, 1982), but $N$. nana also continues through the rest of the Kimmeridgian as a subordinate species. However, both the relative abundances of $N$. nana and $N$. virgula as well as the range of variability of the latter appear to be strongly facies-dependent, so that the value of $N$. virgula as a stratigraphical marker may be limited.

(2) Deltoidum delta (Smith, 1817). The species has been described by Arkell (1932, p. 149-55), and becomes common towards the top of the Oxfordian, where it flourished in large numbers in the Trigonia clavellata Beds. In the Kimmeridgian it is abundant in the lowest part (Baylei-?Lower Cymodoce Zone), where it can be rock-forming in the Ostrea delta beds. Thereafter it becomes rare or absent in Britain and Arkell (1932) recorded no specimen from any higher levels. Rare but otherwise typical $D$. delta has however now been found at Westbury well up in the Mutabilis Zone (M12 and M15) at isolated levels, perhaps suggesting a strongly facies-dependent habitat. 
(3) Nicaniella ('Astarte') supracorallina (d'Orbigny). Chavan (1945) introduced the genus Nicaniella in order to separate the small trigonal to trapezoidal species from Astarte s.s. Astarte supracorallina was founded by d'Orbigny without description (1850, $\mathrm{p}$. 15). The type series did however include, besides material in the d'Orbigny collection in Paris, the shell described and figured as A. minima by Goldfuss (1837, p. 192, pl. 134, fig. 15) non Phillips (1829), thereby escaping the status of nomen nudum assumed by Cox and Arkell (1948, p. iv) for many other Jurassic species of mollusca founded in the Prodrome. Whether the common and widespread species in the English Lower Kimmeridge Clay is in fact correctly identified as 'A..' supracorallina may not be easy to tell and is not important for the present purposes. It is the name that has been consistently used by English authors since the time of Blake (1875, p. 227), including Roberts (1892), Arkell (1947) and Cox and Gallois (1976, 1981). At Westbury, N. (Nicaniella) supracorallina is first found in the lower part of the Mutabilis Zone (M5) although is is recorded from the "Sequanian" (Upper Oxfordian) of France (de Loriol \& Pellat, 1874), and probable precursors (subgenus Trautscholdia) go back at least as far as the Lower Callovian (Duff, 1978). Above M5 at Westbury it is common at most horizons, but most profuse in a bed (M17) packed with shell detritus just below the Mutabilis Limestone. It is not certain whether this bed can be correlated exactly with the Supracoralina Bed at Osmington and Black Head on the Dorset coast described by Arkell (1947) and Cox \& Gallois (1981), and with the Supracorallina Bed in the Lower Kimmeridge Clay of eastern England described by Gallois \& Cox (1976), where it lies closer to the top of the Mutabilis Zone than at Westbury, but this may be the consequence of a slightly different definition of the base of the Eudoxus Zone from the one adopted here (see p. 306).

(4) Pentacrinus. The Pentacrinus Bed (M8) is a very useful marker horizon. Although no complete specimens of the crinoid have been found, the abundance and rapid weathering-out of the fragments makes it easily recognizable. The position of the bed in the middle of the Mutabilis Zone at Westbury correlates with the Pentacrinus Band of Gallois \& Cox (1976) and Cox \& Gallois (1981) elsewhere in southern England.

(5) Saccocoma. The horizons containing this very useful marker have still to be found at Westbury.

\section{(d) Organic carbon and carbonate content}

Analysis for organic carbon and carbonate was carried out by standard techniques. $200 \mathrm{mg}$ of crushed sample was heated to high temperature in pure oxygen until the formation of $\mathrm{CO}_{2}$ had ceased. The $\mathrm{CO}_{2}$ was estimated by infra-red spectrometry and calibrated to yield the percentage of total carbon in the original sample. Organic carbon alone was obtained by the same technique after prior treatment with hot concentrated $\mathrm{HCl}$ for 24 hours. The carbonate content was then calculated by difference, assuming that all the inorganic $\mathrm{CO}_{2}$ originated in calcium carbonate.

The results are plotted in Fig. 2. They show a broadly inverse correlation between carbonate and organic carbon. The amount of organic carbon does not however correlate with the colour of the weathered rock at outcrop. The highest organic content $(16.5 \%)$ occurred in the 'oil shale' at the base of bed E5.

\section{CORRELATIONS AND AMMONITE ZONATION}

\section{(a) Eastern England}

There is a general correspondence, both faunal and lithological, between the succession at Westbury and the borings around the Wash. Thus the C6-M1 boundary at Westbury lies somewhere in Gallois \& Cox's bed (GC)12,; the light-coloured clays with Rasenioides lepidulus and askepta, M1, corresponds to GC 13-15; the change to dark clays M2-6 parallels GC 16-17; the change back to lighter, calcareous silty clays at the base of M7, GC 18. Bed M8 in particular with its pentacrinoid ossicles, echinoid spines, Lopha and Pinna appears to have its equivalents within GC 18. Nicaniella ('Astarte supracorallina' auctt.) reaches its acme in M17 and GC 22, and the black clay of M16 immediately below may correspond to GC 20 , both with an ammonite plaster of $A u$. eulepidus. Aspidoceras appears in the Mutabilis Limestone, M18, and in a similarly calcareous level in GC 24 . The sharp faunal change from Aulacostephanoides to Aulacostephanus appears to have its equivalent at the base of GC 26 or slightly higher, although there is said to be some overlap in the ranges of these genera around the Wash. The Crussoliceras Bed, E6, lies in the middle of GC 30.

Correlation bed by bed closer than this is not possible. The subdivision of a section into beds is to some extent arbitrary, depending on changes in lithology or biofacies that are used to define the boundaries of the beds. The ability to detect such changes differs in borings and at outcrop. In the section at Westbury described here, the division into beds reflects changes in facies clearly visible on a moderately weathered, rain-washed slope, marked by sharp changes in colour or other details of lithology. Many of these had escaped detection in the adjacent borehole through the same succession. The C6-M1 boundary, for instance, was not recorded. Instead, the base of GC 15 was drawn at an interburrowed junction $1.4 \mathrm{~m}$ above the base of M1 that was quite inconspicuous at outcrop and recorded there as merely 
TABLE 1. Correlation of the successions at Westbury and the Aquitaine Basin, western France.

A Q UITAINE B A S N

WEST B URY

(H)

Zone Subzone

Horizon

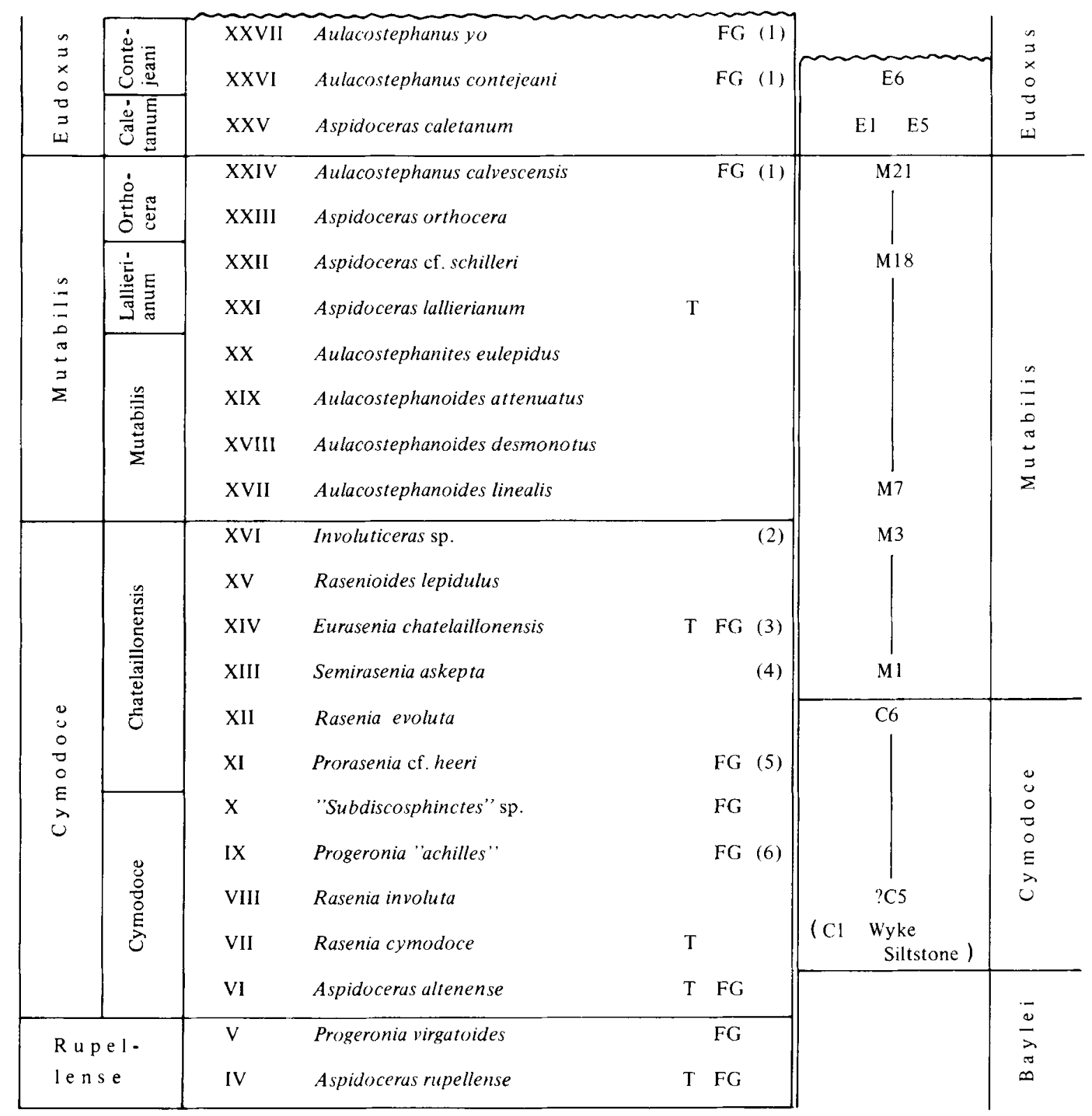

$\mathrm{T}$ Type horizon of the index-species

FG Franco-German species, sub-Mediterranean Province, not found in England

H Hantzpergue, 1979 
a shell-bed within M1. Conversely, a strongly interburrowed junction between M8 and M9 was not noted in the borehole and the heavily interburrowed junction between M21 and E1 would have escaped detection entirely had it not been for the radical change in the abundant ammonite faunas. Thus the 13 or so beds (upper GC 12-GC 25) into which the Mutabilis Zone is divided in eastern England are represented by 21 beds at Westbury. The most precise indicators for correlations continue to be the faunas. It remains in particular to examine more closely the numerous successive faunas of Rasenioides and Aulacostephanoides. As the record of the section shows, there are at least 15 within the Mutabilis Zone at Westbury. The rather general and long-ranging use of such names as Au. mutabilis, Aut linealis or Au. eulepidus conceals more subtle differences between successive faunas not yet studied in detail.

\section{(b) France: the Paris and Aquitaine Basins}

The correlation of the Kimmeridgian of Britain with that of the rest of Europe has presented long-standing problems, arising from the faunal provincialism of the ammonites. The standard successions of sub-Boreal Britain (Lower Kimmeridge Clay) and subMediterranean southern Germany and France (White Jura $\gamma-\varepsilon$ ) have very little in common. Much progress has come from systematic studies of the equivalent strata in central France, in which the faunas overlap. The standard for comparisons in this region has been set up in the northern part of the Aquitaine Basin (A) in which the succession is most complete and fossiliferous (Hantzpergue, 1979). It can then be carried eastwards into the southern and south-eastern parts of the Paris Basin (Hantzpergue \& DebrandPassard, 1980; Contini \& Hantzpergue, 1975). The relevant part of the succession in Aquitaine (Table 1) consists of 24 ammonite horizons of varying abundance and diversity, many of which can be correlated with Westbury of Dorset. The lowest is (A)
VII, the horizon of Rasenia cymodoce itself, whose type came from near La Rochelle. British Rasenia most closely resembling $R$. cymodoce occurs in the Wyke Siltstone on the Dorset coast. Equally close matches can be found in a well-defined horizon in East Greenland, the highest of four there showing the evolutionary transition from Pictonia to Rasenia. The abrupt arrival of $R$. cymodoce in Aquitaine reflects therefore an invasion from the north displacing temporarily the faunas of more southerly affinities that had ruled hitherto ((A) IV-VI). The youngest level with abundant Rasenia in England, C6, correlated with (A) XII, in which $R$. evoluta occurs together with Eurasenia manicata (Schneid), a Swabo-Franconian native found there in the Zone of Crussoliceras divisum, middle White Jura $\gamma$. The replacement of Rasenia by the fine-ribbed group of Rasenioides lepidulus and $R$. (Semirasenia) askepta leading up to Involuticeras ((A) XIII-XVI) occurs in Aquitaine just as it does at Westbury (M1-M3). Even the common occurrence of Nanogyra virgula - the 'facies virgulien', or one-time Virgulian Stage of French authors-begins at almost the same level, (A) XII and M1 (see p. 302) although here its appearance in England probably reflects a northerly migration. The abundance of unispinose Aspidoceras (Orthaspidoceras) in the upper part of the Mutabilis Zone at Westbury has its parallel in (A) XXII-XXIII, and the change to bispinose $A$. (Aspidoceras) coinciding with the abrupt appearance of Aulacostephanus eudoxus ((A) XXV) allows the Mutabilis-Eudoxus boundary to be recognized almost as sharply in Aquitaine as in England. Finally, the Crussoliceras Bed, E6, correlates with (A) XXVI which, in the eastern Paris Basin, yielded the type of Cruss. sevogodense as already noted.

\section{(c) Boundaries and subdivisions of the Cymodoce and Mutabilis Zones.}

Table 1 shows that the Cymodoce and Mutabilis Zones are interpreted in different senses in Britain and in

TABLE 1. Correlation of the successions at Westbury and the Aquitaine Basin, western France.

(1) A group endemic in France and southern Germany but not found in Britain, assigned in part to Pararasenia Spath as subgenus by Ziegler (1962); but it is doubtful whether the Mexican group for which this genus was founded is at all closely related.

(2) Compressed, involute members of the 'fine-ribbed late rasenids' that include Rasenioides; fore-runners of Aulacostephanoides linealis without interruption of the ribbing on the vester.

(3) Eurasenia is another group endemic in France and southern Germany but not found in Britain-the so-called 'German Rasenids' monographed by Schneid (1939) and Geyer (1961). Eu. chatellaillonensis Morris MS (1968, Thesis, Oxford, unpublished) has yet to be validly defined.

(4) Semirasenia Geyer, 1961, for the group of S. moeschi, S. askepta, the macroconchs of Rasenioides, of which it could be made subgenus or synonym.

(5) Prorasenia Schindewolf, 1925, is widely used for the microconchs of the 'German Rasenids', Eurasenia, see (3) above, as well as the true sub-Boreal Rasenia s.s. as found in Britain.

(6) Most of the syntypes of Amm. achilles d'Orbigny (1850, p. 540, pl. 207), a name deeply entrenched in the literature, came from this horizon in the area of La Rochelle. Unfortunately, the lectotype has been chosen to be another syntype that came from the Upper Oxfordian of Burgundy (Tintant, in Loreau \& Tintant, 1968) and the P. 'achilles' auctt. from this horizon IX must await a new name. 
France. A third and even more divergent Mutabilis Zone has at times been used in southern Germany for the lower part of the Acanthicum Zone. With the close correlations now emerging it becomes desirable to unify and stabilize usage in the different areas.

Salfeld's scheme of zones, including Baylei, Cymodoce and Mutabilis Zones, was set up for what he explicitly recognized to be a distinct NW European faunal province $(1914$, p. 240) incorporating NW Germany, the Boulonnais, Normandy and Britain. In NW Germany ammonites are scarce and intermittent. In the Boulonnais there are excellent sections in the Eudoxus and Autissiodorensis Zones, but the boundary between Eudoxus and Mutabilis Zones has not been closely located (Ziegler, 1962) and the Mutabilis and lower Zones do not appear to be exposed. In Normandy only the Baylei and Cymodoce Zones are well developed, but both are highly condensed and together yield ammonites from only three horizons. Thus, by far the most extensive, complete and well-exposed successions are those in Britain, and it is here that the standard successions must be defined.

The Cymodoce Zone was discussed on a previous occasion (Birkelund et al., 1978, p. 35). Four ammonite horizons were distinguished in England: I, horizon of $R$. cymodoce (in the Wyke Siltstone of the Dorset coast); II, $R$. involuta; III, $R$. evoluta; and IV, $R$. askepta. Since then, several further horizons have been recognized in eastern England, Normandy and East Greenland and it has become clear that the dividing-line between Baylei and Cymodoce Zones is going to be determined largely by convenience. The pit at Westbury exposed only horizons III and IV, with perhaps II, and therefore contributes little to the problem. It seems best to defer formal definition of the Cymodoce Zone, in terms of its base in a type section, until the relationships between all the horizons have been more fully worked out, despite Cox \& Gallois' statement $(1981$, p. 14) that '(the Wyke Siltstone) therefore defines the base of the zone'. Should this definition be adopted, however, the base of the Zone would have to be drawn between Horizons VI and VII in Aquitaine (see Table 1), one horizon higher than previously.

The boundary between Cymodoce and Mutabilis Zones has been particularly nebulous. As mentioned above, it has been transitionally put at the level at which 'Rasenia' changes to 'Aulacostephanus', meaning the transition from Rasenioides to Aulacostephanoides by the development of a ventral smooth band. This interpretation was followed by Birkelund $e t$ al. (1978), so that their horizon IV ( $R$. askepta) was still included in the Cymodoce Zone, and by Gallois \& Cox (1976) and Cox \& Gallois (1981).

The transition is gradual-at Westbury it cannot be located more closely than as somewhere between M3 and M8-and so it has led to differences of interpretation (Arkell \& Callomon, 1961; Ziegler, 1963). The new information from Westbury makes it clear, however, that this traditional boundary is gradual, difficult to recognize with limited material, hard to locate on the scale of correlations now being attempted even when material is good, and that Rasenioides and Aulacostephanoides are merely successive evolutionary stages of the same lineage, the transition between which is of relatively little significance. It is not 'the' transition from Rasenia to Aulacostephanus, for Rasenia and Rasenioides are quite independent groups, both phyletically and provincially, and it is the distinction between these two that is profound. We should like to propose that the base of the Mutabilis Zone be drawn in Britain at the level at which 'the fine-ribbed Rasenids' suddenly become dominant, i.e. replace the previously dominant coarse-ribbed Rasenia s.s. At Westbury this is the junction between $\mathrm{C} 6$ and M1, and as shown above, this level can be traced into about the middle of bed GC12 in eastern England. On the Dorset coast it lies immediately above Cox \& Gallois' 'Xenostephanus bed' (recte Rasenia ex gr. evoluta). In Scotland it lies somewhere between the First and Second Limestones at Eathie, Cromarty (Waterston, 1951; confirmed during a brief visit in 1979, and probably locatable more precisely), the type locality of $R$. askepta Ziegler. In Aquitaine it lies between Horizons (A) XII and (A) XIII (Table 1) and is thus a level that can be followed precisely over a large area.

The cumulative evidence of Westbury, Warlingham and eastern England shows also that the Mutabilis Zone will be subdivisible into Subzones, e.g. Askepta Subzone for the lowest part, with Rasenioides; Mutabilis Subzone for a middle part with $A u$. mutabilis and $A u$. eulepidus; and the Orthocera Subzone of Aquitaine for the highest part with Aspidoceras. Formal definition must, however, await further evaluation of the ammonites.

The Eudoxus Zone in an unambiguously chronostratigraphical (Oppelian) sense goes back to Neumayr (1873, p. 211, 'Zone des Per. eudoxus and eumela'; 1887, p. 269, 319) for all the strata between Oppel's Tenuilobatus Zone and the Tithonian in the whole of NW Europe (Germany, France and England). In England it was used in the sense of 'Aulacostephanus beds' by among others Spath, interchangeably with Pseudomutabilis Zone; and to-day's restricted usage both in Britain and southern Germany, introduced by Ziegler (1962), is now firmly established. It remains only to define it formally in terms of its base in a type section. The best biostratigraphical marker is the faunal break between predominantly fine-ribbed Aulacostephanoides and predominantly coarse-ribbed Aulacostephanus that is widely recognizable and which appears to be fairly sharp everywhere: between beds GC 25 and 26 in eastern England (slightly higher than the level taken by Gallois \& Cox); between Horizons 
(A) XXIV and (A) XXV in Aquitaine (see Table 1); and near the boundary between White Jura $\delta 2$ and $\delta 3$ in southern Germany. The only uncertainties could lie in the apparently short ranges of faunal overlap reported at many places, and whether this faunal break is really isochronous. At Westbury and Dorset (see Appendix) the break is absolute, and either would therefore make a good type section for the base of the Eudoxus Zone, even if it reflects a short hiatus. Some hesitation in the choice of Westbury might arise from the possible impermanence of the exposure, but this could be only a formal difficulty because the degree to which the faunal break is recognizable elsewhere in Britain is independent of the precise place at which it is defined.

\section{ACKNOWLEDGEMENTS}

We are grateful to Messrs. M. A. Easton and E. D. Knights, General Works Managers, and their colleagues at the Blue Circle Portland Cement Company's Westbury Works for allowing us access to their pit at all times, for providing us with a description by R. W. Gallois (I.G.S.) of a boring near the pit, and for their hospitality during two prolonged stays to do field-work. We thank also F. T. Fürsich (Munich) for help with the identification of bivalves, B. Buchardt for assistance in the field, P. Wrang (Geological Survey of Greenland) for the carbon analyses, and K. Nielsen, H. Egelund, J. Aagaard and $O$. Berthelsen for help in the preparation of text and illustrations. Financial support by N.E.R.C. is also gratefully acknowledged (J.H.C.).

\section{References}

ARKELL, W. J. 1932. In: A monograph of British Corallian Lamellibranchia. Monogr. palaeontogr. Soc. London, xxxviii $+392 \mathrm{p}$.

- 1933. The Jurassic System in Great Britain. Clarendon Press, Oxford, xii $+681 \mathrm{p}$.

-. 1947. The geology of the country around Weymouth, Swanage, Corfe and Lulworth. Mem. geol. Surv. G.B. $\mathrm{xii}+386 \mathrm{p}$.

—_. 1957. In (Arkell, W. J., B. Kummel \& C. W. Wright) Mesozoic Ammonoidea, L80-L437, in (Moore, R. C., ed.) Treatise on invertebrate paleontology. Part L. Mollusca 4, Cephalopoda, Ammonoidea. Geological Society of America and University of Kansas Press. New York and Lawrence.

—. \& J. H. CALLOMON. 1963. Lower Kimmeridgian ammonites from the drift of Lincolnshire. Palaeontology, 6, 219-45.

BIRKELUND, T., B. THUSU \& J. VIGRAN. 1978. Jurassic-Cretaceous biostratigraphy of Norway, with comments on the British Rasenia cymodoce Zone. Palaeontology, 21, 31-63.

BEURLEN, K. 1958. Die Exogyren. Ein Beitrag zur phyletischen Morphogenese der Austern. N. Jb. Geol. Paläont. Monatsh. 5, 197-217.

BLAKE, J. F. 1875. On the Kimmeridge Clay of England. Q. Jl. geol. Soc. Lond 31, 196-233.

CALLOMON, J. H. 1971. Lower Kimmeridge Clay. In (Callomon, J. H. \& J. C. W. Cope. 1971 (q.v.)) 152-68.

- \& J. C. W. COPE, 1971. The stratigraphy and ammonite succession of the Oxford and Kimmeridge Clays in the Warlingham borehole. Bull. geol. Surv. G.B. 36, $147-76$.

CHAVAN, A. 1945. Les lamellibranches heterodontes des sables Astartiens de Cordebulge (Calvados). Jour. Conchyl., 86, 41-88.

CONTINI, D. \& P. HANTZPERGUE. 1975. Le Kimméridgien de Haute-Sáône. Ann. Sc. Univ. Besancon, Géol. fasc. 23, $3^{\mathrm{c}}$ sér, , 143-179.

COPE, J. C. W. 1968. Propectinatites, a new Lower Kimmeridgian ammonite genus. Palaeontology, 11, 16-8.

- - (ed.), 1980. A correlation of Jurassic rocks in the
British Isles. Part two: Middle and Upper Jurassic. Geol. Soc. Lond., Special Report No. 15, 109 p.

COX, B. M. \& R. W. GALLOIS. 1981. The stratigraphy of the Kimmeridge Clay of the Dorset type area and its correlation with some other Kimmeridgian sequences. Rep. Inst. Geol. Sci., No. 80/4, 44 p.

DUFF, K. L. 1978. Bivalvia from the English Lower Oxford Clay (Middle Jurassic), Monogr. palaeontogr. Soc. London, 137 p.

ENAY, R. 1959. La stratigraphie du Jurassique supérieur dans la chaine anticlinale Faucille-Grand Crêt d'Eau.C. $R$. Acad. Sci., 248, 125-8.

GALLOIS, R. W. 1978. A pilot study of oil shale occurrences in the Kimmeridge Clay. Rep. Inst. Geol. Sci., No. $78 / 13,26 \mathrm{p}$.

- _ \& B. M. COX 1976. The stratigraphy of the Lower Kimmeridge Clay of eastern England. Proc. Yorkshire Geol. Soc.. 41, 13-26.

GAUTRET, P. \& P. HANTZPERGUE. 1982. Utilisation biostratigraphique du genre Nanogyra Beurlen dans le Jurassique supérieur nord-Aquitaine. ge Réunion ann. Sci. Terre, Paris, edit. Soc. géol. France, 1 p.

GEYER, O. F. 1961. Monographie der Perisphinctidae des unteren Unterkimeridgium (Weisser Jura $\gamma$, Badenerschichten) im süddeutschen Jura. Palaeontographica, A, 117, $157 \mathrm{p}$.

GOLDFUSS, A. 1837. Petrefactia Germaniae Pt II, 144-224, pls 122-146. Düsseldorf.

HANTZPERGUE, P. 1979. Biostratigraphic du Jurassique supérieur nord-aquitain. Bull. Soc. Géol. France, 21, 715-25.

- _. \& S. DEBRAND-PASSARD. 1980. L'Oxfordien supérieur et le Kimméridgien des Charentes (Bassin aquitain) et du Berry (Bassin parisien). Extension géographique des repères ammonitiques. Bull. Sac. géol. France 22, 369-75.

LOREAU, J. P. \& H. TINTANT. 1968. Le calcaire de Tonnerre et les formations adjacentes du Jurassique de l'Yonne. Observations stratigraphiques et palćontologigues. Bull. Soc. géol. France (7), 10, 341-57.

LORIOL, P. de \& E. PELLAT. 1874-75. Monographie 
paléontologique et géologique des étages supérieurs de la formation Jurassique des environs de Boulogne-sur-mer. Mém. Soc. Physique et d'Hist. Nat. Genève, 23, 253-407 (1874); 24, 1-326 (1875).

MESEZHNIKOV, M. S. 1969. Fundamental section of the Upper Jurassic of Kheta River Basin. 'Nauka', Leningrad, 207 p. (in Russian).

NEUMAYR, M. 1873. Die Fauna der Schichten mit Aspidoceras acanthicum. Abh. k. k. geol. R.-A., 5, 141-257.

- 1887. Erdgeschichte. 2. Band: Beschreibende Geologie. Leipzig, xii $+880 \mathrm{p}$.

ORBIGNY, A. d'. 1850. Paléontologie francaise. Terrains Jurassiques, I. Paris 1842-1850.

- 1850 . Prodrome de paléontologie stratigraphique universelle des animaux mollusques et rayonées. Vol 2, 428 p., Paris.

PHILLIPS, J. 1829. Illustrations of the geology of Yorkshire. I. The Yorkshire Coast, $192 \mathrm{p}$. York.

ROBERTS, T. 1892. The Jurassic rocks of the neighbourhood of Cambridge. Cambridge University Press, vii +96 p.

SALFELD, H. 1913. Certain Upper Jurassic strata of England. Q. Jl. Geol. Soc. London, 69, 423-30.

- 1914 . Die Gliederung des oberen Jura in Nordwesteuropa von den Schichten mit Perisphinctes Martelli
OPPEL an aufwärts auf Grund von Ammoniten. $N . J b$. Miner., Beil.-Bd. 37, 125-246.

SCHNEID, TH. 1939. Über Raseniiden, Ringsteadiiden und Pictoniiden des nördlichen Frankenjura. Palaeontographica, A 89, 117-84.

1915. Die Geologie der fränkischen Alb zwischen Eichstätt und Neuburg a.D. Geogn. Jahreshefte 27, 59-170.

SHEPPARD, T. 1907. Recent geological discoveries at Speeton. Naturalist, Aug. 1907, 277-9.

SPATH, L. F. 1925. Ammonites and aptychi. In (Gregory, J. W. et al.) The collection of fossils and rocks from Somaliland. Monogr. Geol. Dept. Hunterian Museum, Glasgow University, 1, 111-70.

WATERSTON, C. D. 1951. The stratigraphy and palaeontology of the Jurassic rocks of Eathie (Cromarty). Transact. Royal Soc. Edinburgh, 62, 33-51.

WRIGHT, J. K. 1980. Oxfordian Correlation Chart. In (Cope, J. C. W. (ed) 1980 (q.v.)), 61-75.

ZIEGLER, B. 1962. Die Ammoniten-Gattung Aulacostephanus im Oberjura (Taxionomie, Stratigraphie, Biologie). Palaeontographica A, 119, 1-172.

- 1963. Some Upper Jurassic ammonites of the genus Rasenia from Scotland. Palaeontology, 5, 765-69.

- 1969. Über Exogyra virgula (Lamellibranchiata, Oberjura). Eclogae geol. Helvetiae, 62, 685-96.

\section{Appendix: The boundaries of the Mutabilis Zone on the Dorset coast}

According to Cox \& Gallois (1981) the best sections in the Mutabilis Zone are to be seen on the east side of the prominent ridge running down from the highest point of Black Head but, despite some considerable digging, we were unable to expose the basal and top parts of the Zone in situ in faces that had not slumped to some degree. Instead, these beds were clearly exposed, somewhat weathered but free of slumping and dipping only moderately, in the smaller cliffs west of Osmington Mills, around a small upfaulted block of Corallian.

\section{(a) The boundary between Cymodoce and Mutabilis Zones}

Low cliff at the first good exposure above the beach, $150 \mathrm{~m}$ west of the boat-slip at Osmington Mills (Cox \& Gallois, 1981, p. 34). Reference-points: two pyritic levels weathering to give two yellowish, sulphury bands $c .1 .5 \mathrm{~m}$ apart

\section{From below:}

Cymodoce Zone, upper part

-Clays, black, very fine-grained, moderately fossiliferous, most shells broken examined Rasenia evoluta $[\mathrm{M}]$ and $[\mathrm{m}]$

$$
\text { - passing up into - }
$$

-Lower pyritic bed: clays, black, highly fossiliferous, pyritic, somewhat laminated. Thracia depressa (VC), Isognomon $(\mathrm{C})$. Ammonites common:

Rasenia evoluta $[\mathrm{M}]$ and $[\mathrm{m}]$

Rasenioides sp. [M] and [m]

in the ratio of $c .4$ to 1 . Passing up into

- Clays, black, still slightly Iaminated, highly fossiliferous. Thracia depressa (VC), Isognomon (C), Liostrea. Ammonites profuse (Cox \& Gallois' 'Xenostephanus Bed'), particularly in an ammonite plaster $0.30 \mathrm{~m}$ up: Rasenia evoluta [M] and [m] (VC) $0.30 \mathrm{~m}$ coarse-ribbed, typical, just like the upper fauna of Market Rasen; numerous venters seen, none with interrupted ribbing:

Rasenioides sp. ( $\mathrm{R}$ ) - inconspicuous boundary Mutabilis Zone

Clays, dark, more massive, non-laminated, very much less fossiliferous. Thracia depressa, Corbulomima.

Rasenioides askeptus (Ziegler) [M] and lepidulus (Oppel) [m] typical, the first in a layer $0.10 \mathrm{~m}$ up - passing into -

-Clays as below, highly fossiliferous. Thracia depressa

(VC), Corbulomima (VC), nuculaceans

Ammonites very common:

Rasenioides askeptus [M] and lepidulus [m], typical.

-Upper pyritic bed: clays, dark, somewhat laminated, pyritic at the base, highly fossiliferous, etc.; continuing upwards

The distance between abundant Rasenia evoluta and Rasenioides askeptus/lepidulus is here only $10 \mathrm{~cm}$, even less than at Westbury, and the faunal break is equally great. Lithologically, the boundary between Cymodoce and Mutabilis Zones is barely detectable, reflected mainly in a slight chfinge in the degree of lamination. The nonammonoid faunas change somewhat: calcareous oysters and Isognomon are replaced by Corbulomima, but Thracia ranges through.

(b) The boundary between the Mutabilis and Eudoxus Zones Moderately high cliff rising to a promontory immediately beyond the faulted block of Corallian, c. $200 \mathrm{~m}$ west of the 
boat-slip at Osmington Mills (Cox \& Gallois, 1981, p. 34). Reference point: prominent thin band of tabular siltstone rising to the skyline near the top of the cliff (Osmington Mills Siltstone: new name, here).

From below:

Mutabilis Zone, upper part

-Clays, highly calcareous, well laminated, more or less packed with fossil brash, slightly pyritic and weathering yellow at the skyline; including the Supracorallina Bed some $2 \mathrm{~m}$ below the top. Not studied in detail.

-Osmington Mills Siltstone: thin, impersistent but prominent calcareous fine-grained siltstone, weathering into tabular slabs, moderately laminated. Occasiona bivalves: Grammatodon. Some ammonites, mostly broken

Aulacostephanoides cf. or aff. mutabilis [M] (C)

Aulacostephanoides linealis (C)

Aspidoceras (Orthaspidoceras) sp.

-Clays, calcareous; highly fossiliferous, much shell debris: Thracia depressa (VC), whole and fragmentary

Many ammonites throughout, all very densely and finely ribbed with ventral smooth band, ranging from discoidal to evolute:

Aulacostephanoides linealis-desmonotus $[\mathrm{M}]$ and $[\mathrm{m}]$ terminating with a layer of complete adult $A u$. linealis and Thracia depressa.

$$
\text { - sharp boundary - }
$$

-Clays, dark, massive, less calcareous, sparsely fossiliferous. Small nuculaceans, scattered shell fragments, including ammonites

Aulacostephanus eudoxus [m] (R), fragments, coarseribbed, at +0.05 and $+0.10 \mathrm{~m}$ up; no trace of fine-ribbed forms.

-Clays, dark, slightly pyritic, more fossiliferius: Nanogyra virgula, Liostrea, and profuse broken shells Aulacostephanus eudoxus [m], typical, at top Amoeboceras (Amoebites) ef. elegans Spath, at $+0.20 \mathrm{~m}$ Laevaptychus $[\mathrm{m}]$

- Clays, dark, slightly laminated, profusely fossiliferous. Thracia depressa (VC), Nanogyra virgula (C), Liostrea juv. (VC), Corbulomima, Nicaniella (R). Examined to Aulacostephanus eudoxus $[\mathrm{m}]$, with lappets, coarsely to fairly densely ribbed (C)

$0.10 \mathrm{~m} \quad$ Aulacostephanus pseudomutabilis [M] at $+0.20 \mathrm{~m}$ up Amoeboceras (Hoplocardioceras?) sp at $+0.20 \mathrm{~m}$ up Sutneria cyclodorsata (Moesch) at +0.20 and $+0.30 \mathrm{~m}$ up

Aspidoceras sp. s.s. $[\mathrm{m}]$ at $+0.20 \mathrm{~m}$ up, and $[\mathrm{M}]$

Laevaptychus [m] (VC) throughout

$0.30 \mathrm{~m}$

$0.30 \mathrm{~m}$

$0.40 \mathrm{~m}$

Hence the faunal break is here as sharp as at Westbury. The break occurs slightly higher than indicated by Cox and Gallois, who already included the Osmington Mills Siltstone in the Eudoxus Zone. It seems useful to name this bed explicitly; it joins the Wyke Siltstone and Black Head Siltstone as important markers in the otherwise rather featureless Lower Kimmeridge Clay. 